\title{
NATURAL OCCURRENCE, BIOLOGICAL ACTIVITIES AND SYNTHESIS OF EIGHT-, NINE-, AND ELEVEN- MEMBERED RING LACTONES
}

Helena M. C. Ferraz ${ }^{\dagger}$ and Fernanda I. Bombonato

Instituto de Química, Universidade de São Paulo, CP 26077, 05513-970 São Paulo - SP, Brazil

Myrian K. Sano

Universidade Anhembi Morumbi, Campus Centro, Rua Dr. Almeida Lima, 1134, 03164-000 São Paulo - SP, Brazil

Luiz S. Longo Jr.*

Universidade Federal de São Paulo, Campus Diadema, Rua Prof. Artur Ridel, 275, 09972-270 Diadema - SP, Brazil

Recebido em 17/1/08; aceito em 7/4/08; publicado na web em 30/4/08

\begin{abstract}
NATURAL OCCURRENCE, BIOLOGICAL ACTIVITIES AND SYNTHESIS OF EIGHT-, NINE-, AND ELEVEN-MEMBERED RING LACTONES. The natural occurrence, biological activities and synthetic approaches to natural eight-, nine-, and elevenmembered lactones is reviewed. These medium ring lactones are grouped according to ring size, and their syntheses are discussed. The structures of some natural products early identified as medium-ring lactones were revised after total synthesis.
\end{abstract}

Keywords: medium ring lactones; synthesis; natural products.

\section{INTRODUCTION}

About ten years ago, Kao et al. ${ }^{1}$ wrote: "The chemical synthesis of functionalized eight-membered ring lactones (2-oxocanones) is extremely challenging, and virtually no functionalized eightmembered ring lactones are known among natural products." In fact, these lactones, as well as those of nine- and eleven-membered ring, are not so abundant in the Nature as their congeners containing a ten-membered ring. ${ }^{2}$

Recently, the synthetic approaches toward the naturally occurring ten-membered ring lactones (decalactones) were revised by us. ${ }^{3}$ More specifically, Riatto et al. ${ }^{4}$ reviewed the synthetic studies of decarestrictine family, an important class of decalactones. Another recent review, dealing with the total syntheses of some eight- and nine-membered ring lactones, was published by Shiina. ${ }^{5}$

Herein, we wish to review the natural occurrence and biological activities of the eight-, nine- and eleven-membered ring lactones, and to summarize the approaches for their syntheses. For those syntheses already reviewed somewhere else, only a brief discussion of the lactonization step will be presented here, in order to provide a global panorama to the reader. Beyond the scope of this review are the synthetic unnatural eight-, nine- and eleven-membered lactones.

\section{EIGHT-MEMBERED RING LACTONES}

\section{Penicillide and derivatives}

The dibenzodioxocanone named (+)-penicillide (1) was first isolated in 1974, by Sassa et al., ${ }^{6}$ from Penicillium sp. Later, this metabolite was found, along with dehydroisopenicillide (2), in the extract of Talaromyces derxii, and its absolute configuration was established. ${ }^{7}$ In 1992, Proksa et al. ${ }^{8}$ reported the isolation of the metabolites vermixocins A and $\mathrm{B}$, from $P$. vermiculatum. Recently, the structures of vermixocins A and B were determined as being the same as those of penicillide (1) and (-)-purpactin A (3),

\footnotetext{
In memoriam

*e-mail: luiz.longo@unifesp.br
}

respectively, which were isolated from $P$. simplicissimum. ${ }^{9}$ Purpactin A (3) was also isolated from $P$. purpurogenum in 1991, and showed inhibitory effect of acyl-CoA-colesterol acyltransferase, an enzyme involved in choslesterol ester accumulation in atherogenesis and in cholesterol absorption from the intestines. ${ }^{10}$

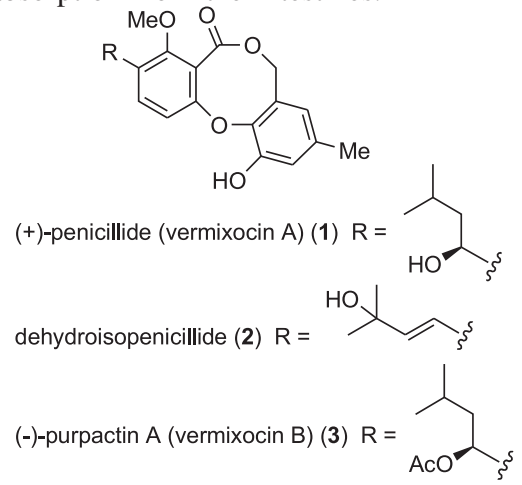

Penicillide (1) and several related compounds were shown to be antagonists of the peptide hormone oxytocin ${ }^{11}$ as well as inhibitors of cholesterol ester transfer protein (CETP). Inhibition of CETP may have a beneficial action in enhancing high-density lipoprotein cholesterol (HDL) levels. ${ }^{12}$ Epidemiological studies show that low levels of HDL is a risk factor for the development of coronary heart diseases.

Although several research groups deal with the biological aspects of penicillide and its derivatives, ${ }^{11}$ there is no report, to our knowledge, concerning the total synthesis of these compounds.

\section{Ovatolide}

(-)-Ovatolide (4) is a tetracyclic indole alkaloid bearing an eightmembered ether-lactone, found in the leaves of Bridelia ovata, a Thailandian plant used in folk medicine as laxative, febrifuge and adstringent. ${ }^{13}$

A total synthesis of (-)-4 was developed by Delgado and Clardy, ${ }^{13}$ as summarized in Scheme 1. The $\beta$-glucosidic linkage of $\mathbf{6}$ was constructed via the reaction of the 4-hydroxy-5-(benzyloxy)indole derived from 5 with the epoxysugar $\mathbf{9}$, in a regio- and stereocontrolled 
manner. The authors used the Corey-Nicolaou protocol ${ }^{14}$ in the lactonization step, and the eight-membered lactone $\mathbf{8}$ was obtained in $72 \%$ yield after treatment of 7 with 2,2'-dipyridyl disulfide (pySSpy) and triphenylphospine. Deprotection of indole nitrogen atom and hydroxyl groups of the glucoside subunit led to (-)-ovatolide (4).

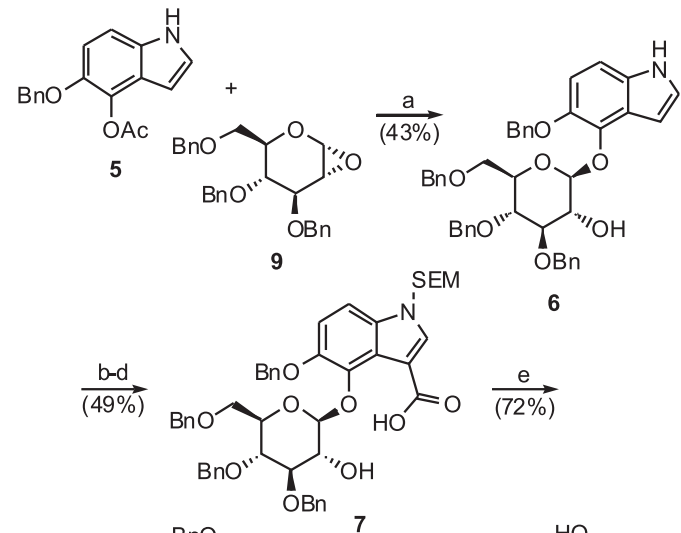<smiles>O=C1O[C@@H](O)[C@H]2OC(=O)[C@@H](CO)[C@H](O)[C@@H](O)[C@H]2Oc2c(O)ccc3[nH]cc1c23</smiles>

(-)-ovatolide (4)

Scheme 1. Reagents and conditions: (a) i: $\mathrm{NaOH}-\mathrm{Na}_{2} \mathrm{~S}_{2} \mathrm{O}_{4}, \mathrm{DMF}, 5^{\circ} \mathrm{C}, 15$ min, ii: 15-crown-5, epoxysugar 9, DMF, rt, overnight; (b) TFAA, DMF, $5^{\circ} \mathrm{C}$, $1 \mathrm{~h}$; (c) NaH, THF, $O^{\circ} \mathrm{C}, 15 \mathrm{~min}$, then $0.5 \mathrm{~N} \mathrm{sol}$. of SEMCl in THF (1.5 equiv.), $5^{\circ} \mathrm{C}, 30 \mathrm{~min}$; (d) $\mathrm{NaH}, \mathrm{DMF}, 70^{\circ} \mathrm{C}, 15 \mathrm{~min}$; (e) i: pySSpy, $\mathrm{PPh}_{3}, \mathrm{CH}_{2} \mathrm{Cl}_{2}, \mathrm{rt} 30$ min, ii: $\mathrm{AgClO}_{4}$, benzene, reflux, $45 \mathrm{~min}$; (f) $\mathrm{MS} 4 \mathrm{~A}$, THF, $\mathrm{NH}_{2} \mathrm{CH}_{2} \mathrm{CH}_{2} \mathrm{NH}_{2}$, $\mathrm{TBAF}, 6 \mathrm{O}^{\circ} \mathrm{C}, 3 \mathrm{~h} ; \mathrm{g} \mathrm{g} \mathrm{Pd}(\mathrm{OH})_{2}, \mathrm{EtOAc}, \mathrm{AcOH}, \mathrm{H}_{2}, r t, 2 \mathrm{~h}$

\section{Cephalosporolides}

A group of five lactones, called cephalosporolides B-F (10-14), was produced by fermentation of the fungus Cephalosporium aphidicola, and their structures were elucidated by Ackland et al., in 1985. ${ }^{15}$ Later, cephalosporolide G (15) was isolated from the same fungus by Farooq et al., ${ }^{16}$ along with the known decalactone diplodialide $\mathrm{B}^{17}$ and Z-3-methylpent-2-en-1,5-dioic acid. More recently, Li et al. ${ }^{18}$ reported the isolation of cephalosporolides $\mathrm{H}$ (16) and I (17) from lyophilized culture broth of the fungus Penicillium $s p$. Three of these metabolites are ten-membered ring lactones (cephalosporolides B, C and G), one is an eight-membered ring lactone (cephalosporolide D), and the others (cephalosporolides E, F, H and I) are spiroketal lactones.

According to the authors, ${ }^{15}$ cephalosporolides E (13) and F (14) are probably artefacts of the isolation procedure, arose from cephalosporolide C (11) through a sequence involving an opening of the ten-memebred ring of $\mathbf{1 1}$ followed by relactonization and acetal formation.

In 2005, Oller-López et al. ${ }^{19}$ isolated $\mathbf{1 3}$ and $\mathbf{1 4}$ in the broth culture of the entomoparasitic deuteromycete Beauveria bassiana and found a biosynthetic precursor of these lactones, the butyrolactone bassianolone, which showed antimicrobial activity against gram-positive cocci and fungi. To our knowledge, the biological activities of cephalosporolides were not yet evaluated.

The only reported synthesis of (-)-cephalosporolide D (12), allowing the determination of its relative and absolute stereochemistry, was developed by Shiina et al. ${ }^{20}$ The lactonization of the hydroxyacids $\mathbf{1 8 a} / \mathbf{1 8 b}$ were performed employing different protocols. The use of $\mathrm{Hf}(\mathrm{OTf})_{4}$ as Lewis acid catalyst and $p$-trifluoromethylbenzoic

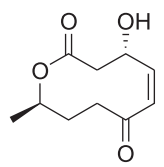

(+)-cephalosporolide B (10)

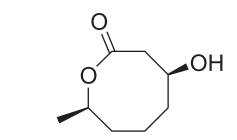

(-)-cephalosporolide D (12)

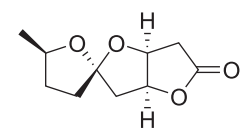

cephalosporolide $\mathrm{F}$ (14)

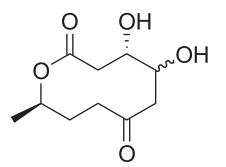

(+)-cephalosporolide C (11) $(\beta-\mathrm{OH})$ $(\alpha-\mathrm{OH})$

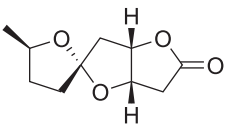

(+)-cephalosporolide E (13)

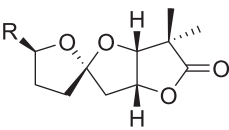

cephalosporolide $\mathrm{H}$ (16)

$\left[\mathrm{R}=-\left(\mathrm{CH}_{2}\right)_{6} \mathrm{CH}_{3}\right]$

cephalosporolide I (17)

$\left[\mathrm{R}=-\left(\mathrm{CH}_{2}\right)_{3} \mathrm{CO}_{2} \mathrm{H}\right]$ cephalosporolide $\mathrm{G}$ (15)

anhydride led to the corresponding eight-membered lactones $\mathbf{1 9 a} / \mathbf{1 9 b}$ in $81 \%$ yield (Scheme 2).

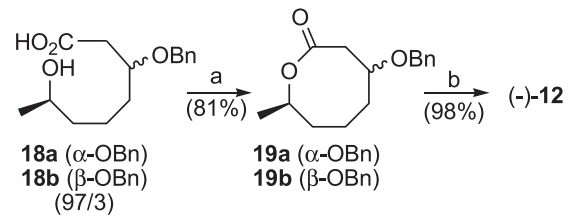

Scheme 2. Reagents and conditions: (a) $\mathrm{Hf}(\mathrm{OTf})_{4},\left(\mathrm{p}-\mathrm{CF}_{3} \mathrm{C}_{6} \mathrm{H}_{4} \mathrm{CO}\right)_{2} \mathrm{O}, \mathrm{CH} \mathrm{CN}_{3}$, $T H F$, reflux (2.34 mM, slow addition over $15 \mathrm{~h}$ period; $81 \%$ yield based on $83 \%$ conversion); (b) $i: \mathrm{H}_{2}, \mathrm{Pd} / \mathrm{C}, \mathrm{EtOH}, \mathrm{rt}$ (4/6 mixture of 12/ent-12); ii: recristallization from hexanes

In 2001 Buszek et al. ${ }^{21}$ synthesized the unnatural (+)cepalosporolide D (ent-12) using the Corey-Nicolaou lactonization method $^{14}$ (Scheme 3).

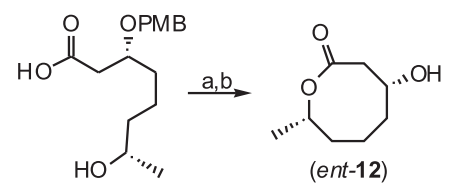

Scheme 3. Reagents and conditions: (a) pySSpy, $\mathrm{PPh}_{3}, \mathrm{CH}_{2} \mathrm{Cl}_{2}, \mathrm{rt}, 2 \mathrm{~h}$, then $\mathrm{AgBF}_{4}$, toluene, reflux, $12 \mathrm{~h}$ (81\%); (b) $\mathrm{DDQ}, \mathrm{CH}_{2} \mathrm{Cl}_{2}, \mathrm{H}_{2} \mathrm{O}$ (yield not given)

\section{Octalactins}

In 1991, the isolation and relative configurations of two lactones, named octalactins A (20) and B (21), were reported by Tapiolas et al. ${ }^{22}$ These highly functionalized eight-membered ring compounds are produced by an actinomycete collected from the surface of a mexican gorgonian octocoral of the genus Pacifigorgia. Octalactin A (20) showed significant in vitro cytotoxicity against some tumor cell lines, while its olefin analogue B was inactive in the cytotoxic assays.

The four total syntheses of octalactins found in the literature, ${ }^{23-26}$ as well as some formal syntheses and related model studies, ${ }^{27}$ were exhaustively discussed by Shiina, in his recent review. ${ }^{5}$ Therefore, only some aspects of the total synthesis will be briefly depicted here.

The first synthesis of both octalactins A (20) and B (21), which establishes their absolute configurations, was performed by Buszek et $a l .{ }^{23}$ The sequence involves as key step an intramolecular esterification of the $\omega$-hydroxy carboxylic acid 22, using a slight 


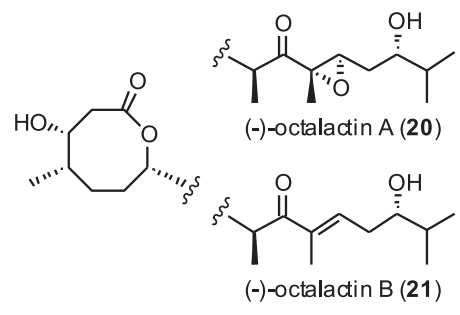

modification of the Corey-Nicolaou protocol, ${ }^{14}$ which led to the eight-memebred intermediate $\mathbf{2 3}$ in $\mathbf{7 3 \%}$ yield (Scheme 4 ). Thus, 23 could be transformed into (-)-20 and (-)-21 after 7 and 6 additional steps, respectively.

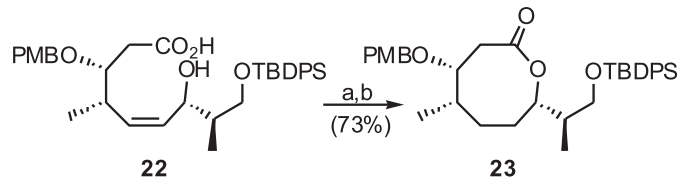

Scheme 4. Reagents and conditions: (a) $\mathrm{H}_{2}, \mathrm{Pd} / \mathrm{C}$; (b) i: pySSpy, $\mathrm{PPh}_{3}, \mathrm{CH}_{2} \mathrm{Cl}_{2}$, $\mathrm{rt}, 8 \mathrm{~h}$; ii: $\mathrm{AgBF}_{4}$, toluene, $110^{\circ} \mathrm{C}, 96 \mathrm{~h}$

McWilliams and Clardy $^{24}$ reported a total synthesis of the unnatural $(+)$-octalactin $\mathrm{A}($ ent-20) and $(+)$-octalactin $\mathrm{B}($ ent-21), using a Baeyer-Villiger expansion of the cycloheptanone derivative 24 using unbuffered trifluoroperoxyacetic acid (Scheme 5).
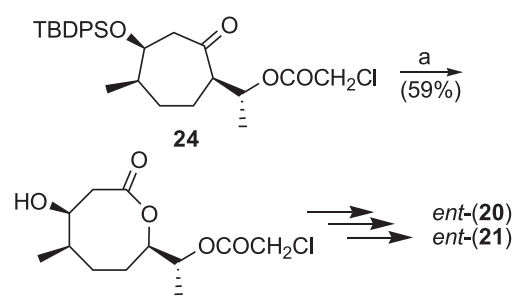

Scheme 5. Reagents and conditions: (a) $\mathrm{i}: \mathrm{HF}, \mathrm{CH}_{3} \mathrm{CN}, \mathrm{rt}, 15 \mathrm{~h}$; ii: $3 \mathrm{M}$ $\mathrm{CF}_{3} \mathrm{CO}_{3} \mathrm{H}, \mathrm{CH}_{2} \mathrm{Cl}_{2},-10^{\circ} \mathrm{C}, 91 \mathrm{~h}$

The asymmetric total synthesis of both octalactins A and B has also been achieved by O'Sullivan et al. in $2004 .^{25}$ The eight-memebred lactone core (27a or $\mathbf{2 7 b}$ ) was obtained by Claisen rearrangement of alkenyl-substituted cyclic ketene acetal, generated in situ by selenoxide elimination of the corresponding selenoacetal $\mathbf{2 5}$ or by olefination of the corresponding carbonate $\mathbf{2 6}$ using dimethyltitanocene (Scheme 6).

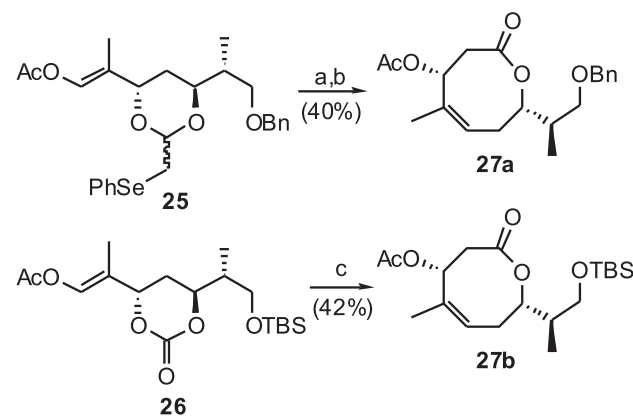

Scheme 6. Reagents and conditions: (a) $\mathrm{NaIO}_{4}, \mathrm{NaHCO}_{3}, \mathrm{MeOH}, \mathrm{H}_{2} \mathrm{O}, 22{ }^{\circ} \mathrm{C}$, 1,5 h; (b) 1-tert-butyldimethylsiloxy-1-methoxy-ethene, xylene, $\mathrm{K}_{2} \mathrm{CO}_{3}$, sealed tube, $180^{\circ} \mathrm{C}, 2,5 \mathrm{~h}$; (c) $\mathrm{Cp}_{2} \mathrm{TiMe}_{2}$, toluene, reflux, $30 \mathrm{~min}$

Shiina et al. ${ }^{26}$ recently reported the synthesis of (-)-octalactin A (20) employing a mixed-anhydride lactonization approach to construct the eight-membered ring moiety. Treatment of seco acid 28 with 2methyl-6-nitrobenzoic anhydride (MNBA) and a catalytic amount of 4-(dimethylamino)pyridine (DMAP) or 4-(dimethylamino)pyridine 1-oxide (DMAPO) afforded the eight-membered lactone $\mathbf{2 9}$ in $90 \%$ yield (Scheme 7).

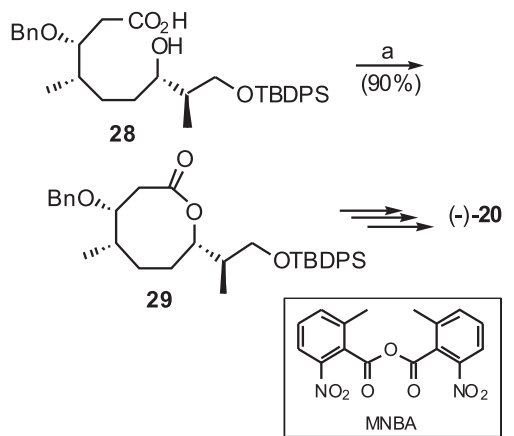

Scheme 7. Reagents and conditions: (a) MNBA, DMAP (10 mol\%) or DMAPO (10 $\mathrm{mol} \%$ ), $\mathrm{Et}_{3} \mathrm{~N}, \mathrm{CH}_{2} \mathrm{Cl}_{2}, \mathrm{rt}$

More recently, an approach to the functionalized eight-membered ring core of octalactins, based on a sequential Evans-Tishchenko and ring closing metathesis (RCM) reactions, was developed by Aird et $a l .{ }^{28}$ The synthesis initially relied on the preparation of chiral aldehydes $\mathbf{3 0}$ and 31, and phosphonate 33, as outlined in Scheme 8. Horner-Wadsworth-Emmons reaction of $\mathbf{3 1}$ and 33, followed by desilylation, furnished the $\beta$-hydroxy enone $\mathbf{3 4}$ as a 95:5 mixture of the E/Z isomers. Evans-Tishchenko coupling of fragment 34 with aldehyde 30, using preformed samarium(III) catalyst, led to dienoic ester $\mathbf{3 5}$ as a single diastereomer. RCM reaction of $\mathbf{3 5}$, using second generation Grubbs catalyst and $\mathrm{Ti}\left(\mathrm{O}^{i} \mathrm{Pr}\right)_{4}$ as Lewis acid, afforded a 1:1 mixture of the eight-membered lactone $\mathbf{3 7}$ and the cyclopentene derivative 36, formed due to a competitive metathesis reaction of the trisubstituted double bond in $\mathbf{3 5}$.

\section{Solandelactones}

The solandelactones A-I (38-46) constitute a group of eightmembered ring lactones isolated in 1996 from Solanderia secun$d a$, a dark-brown hydroid found in the shore of Jaeju Island, in Korea. Solandelactones C (40), D (41), and G (44) exhibit moderate inhibitory activity against FPT (farnesyl protein transferase). ${ }^{29}$

These compounds are lactonized cyclopropyl docosanoids, being probably the first examples of marine oxylipins bearing a C22 carbon skeleton. The biosynthetically related six-membered ring constanolactones $\mathrm{A}$ and $\mathrm{B}^{30}$ and nine-membered ring halicholactones (described further) are derived from eicosanoid $\left(\mathrm{C}_{20}\right)$

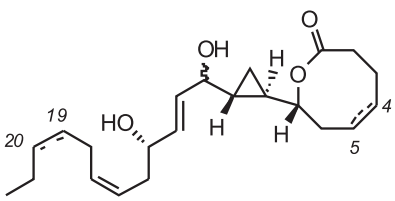

solandelactone A $(38)(\beta-O H)$

solandelactone $B(39)(\alpha-O H)$

solandelactone $C(\mathbf{4 0})\left(\beta-\mathrm{OH}, \Delta^{19,20}\right)$

solandelactone D (41) $\left(\alpha-\mathrm{OH}, \Delta^{19,20}\right)$

solandelactone $\mathrm{E}(\mathbf{4 2})\left(\alpha-\mathrm{OH}, \Delta^{4,5}\right)$

solandelactone $F(43)\left(\beta-\mathrm{OH}, \Delta^{4,5}\right)$

solandelactone G (44) $\left(\beta-\mathrm{OH}, \Delta^{4,5}, \Delta^{19,20}\right)$

solandelactone $\mathrm{H}(\mathbf{4 5})\left(\alpha-\mathrm{OH}, \Delta^{4,5}, \Delta^{19,20}\right)$<smiles>C[C@@H]1C(=O)CCCCC[C@@H]1[C@H]1C[C@H]1/C=C/C(O)C(O)C/C=C\[SnH3]</smiles>

solandelactone I (46) 


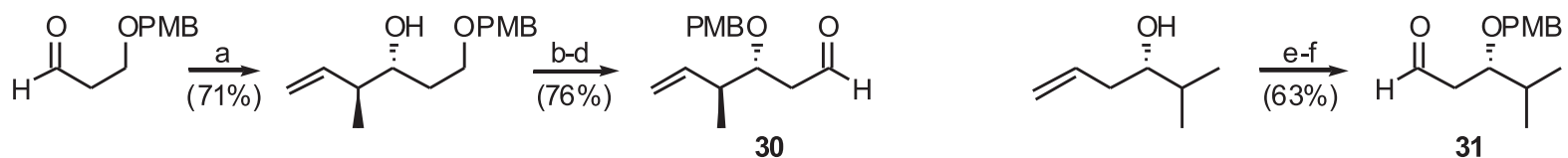

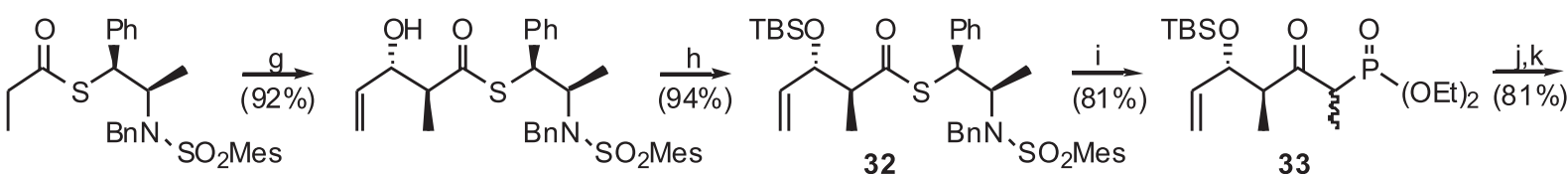

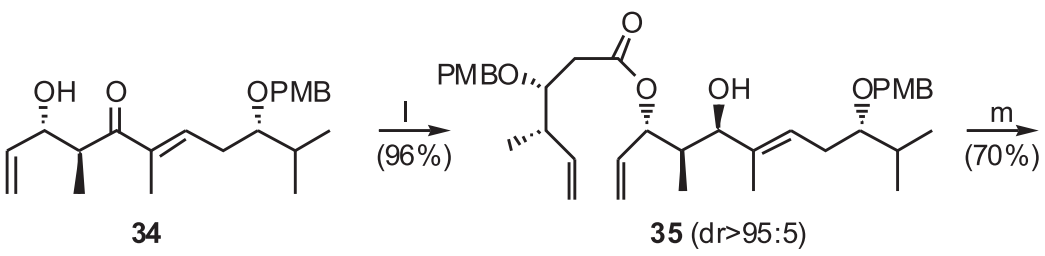<smiles>CC=C[C@@H](C)[C@@H](O)CC(=O)O[C@H]1C=C(C)[C@@H](O)[C@H]1C</smiles>

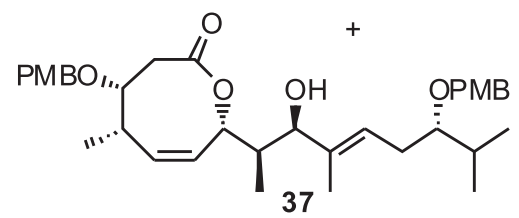

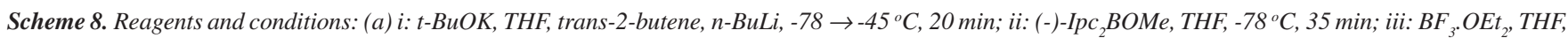
$-78^{\circ} \mathrm{C}, 4 \mathrm{~h}$; (b) DDQ, MS 4A, $\mathrm{CH}_{2} \mathrm{Cl}_{2}, \mathrm{O}^{\circ} \mathrm{C}, 15 \mathrm{~min}$; (c) DIBAL- $\mathrm{H}, \mathrm{CH}_{2} \mathrm{Cl}_{2}, \mathrm{O}^{\circ} \mathrm{C}, 2 \mathrm{~h} ;(\mathrm{d})(\mathrm{COCl}), \mathrm{DMSO}, \mathrm{CH}_{2} \mathrm{Cl}_{2}, \mathrm{Et}_{3} \mathrm{~N},-78^{\circ} \mathrm{C} \rightarrow \mathrm{rt}, 75 \mathrm{~min} ;(\mathrm{e}) \mathrm{PMBCl}, \mathrm{t}-\mathrm{BuOK}$,

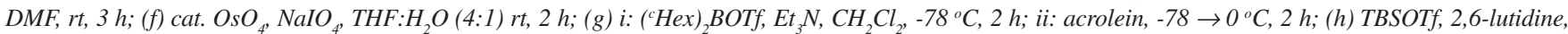
$\mathrm{CH}_{2} \mathrm{Cl}_{2}, \mathrm{O}^{\circ} \mathrm{C}, 70 \mathrm{~min}$; (i) $\mathrm{i}:(\mathrm{OEt})_{2} \mathrm{P}(\mathrm{O}) \mathrm{CH}_{2} \mathrm{CH}_{3} ; \mathrm{n}-\mathrm{BuLi}, \mathrm{THF},-78^{\circ} \mathrm{C}, 1 \mathrm{~h}$; ii: solution of 32 in $\mathrm{THF},-78^{\circ} \mathrm{C}, 1 \mathrm{~h}$; (j) i: $\mathrm{Ba}(\mathrm{OH})_{2} .8 \mathrm{H}_{2} \mathrm{O}, \mathrm{THF}, \mathrm{rt}, 30 \mathrm{~min}$; ii: aldehyde 31, THF: $\mathrm{H}_{2} \mathrm{O}$ (40:1), rt, $24 \mathrm{~h}$; ( $\left.\mathrm{k}\right) \mathrm{HF}, \mathrm{CH}_{3} \mathrm{CN}, \mathrm{rt}, 15 \mathrm{~min}$; (l) (PhCHO) SmI.SmI $_{3}(30 \mathrm{~mol} \%)$, aldehyde 30, THF, $-10^{\circ} \mathrm{C}, 30 \mathrm{~min}$; ( $\left.\mathrm{m}\right) 2^{\text {nd }}$ generation Grubbs catalyst, $\mathrm{CH}_{2} \mathrm{Cl}_{2}, \mathrm{Ti}(\mathrm{Oi}-\mathrm{Pr})_{4}$, reflux, $24 \mathrm{~h}(36 / 37=1 / 1)$

precursors. The original assigment of $\mathrm{C} 11$ of solandelactones $\mathrm{E}$ (42) and F (43) was recently revised by total synthesis. ${ }^{31,32}$

Two different approaches to the synthesis of the cyclopropyllactone segment of solandelactones were developed by Varadarajan et al. ${ }^{33}$ Both strategies were based on the preparation of cyclopropane derivatives $\mathbf{5 0 a} / \mathbf{5 0 b}$, starting from 2,3- $O$-isopropylidene $D$ glyceraldehyde 47 (Scheme 9). Then, 51 could be converted into the eight-membered ring core of solandelactones (52) via a lactonization key step, under Yamaguchi conditions, ${ }^{34}$ or through a

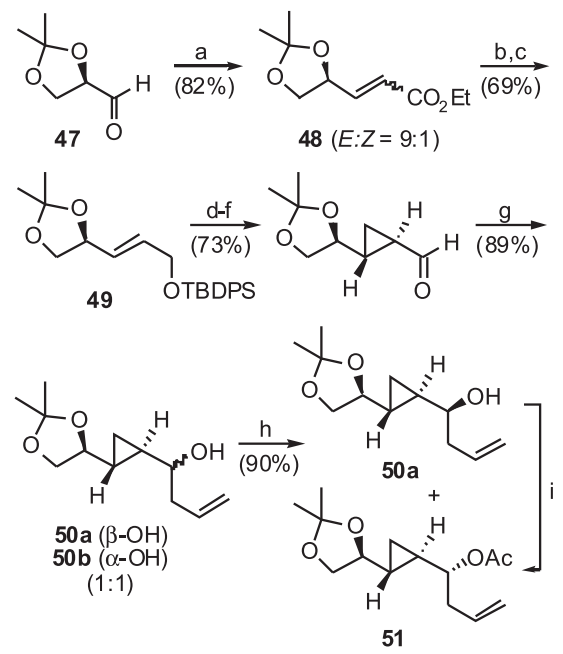

Scheme 9. Reagents and conditions: (a) $\mathrm{Ph}_{3} \mathrm{P}=\mathrm{CHCO}_{2} \mathrm{Et}$, benzene, $90^{\circ} \mathrm{C}$, $6 \mathrm{~h}$; (b) DIBAL-H, $\mathrm{CH}_{2} \mathrm{Cl}_{2},-78 \rightarrow 0^{\circ} \mathrm{C}, 1 \mathrm{~h}$; (c) TBDPSCl, imidazole, $\mathrm{CH}_{2} \mathrm{Cl}_{2}$, $\mathrm{O}^{\circ} \mathrm{C} \rightarrow \mathrm{rt}$, overnight; (d) $\mathrm{Et} 2 \mathrm{Zn}, \mathrm{CH}_{2} \mathrm{I}_{2}, \mathrm{CH}_{2} \mathrm{Cl}_{2},-78^{\circ} \mathrm{C}, 4 \mathrm{~h}$, then $0^{\circ} \mathrm{C}, 20 \mathrm{~h}$; (e) TBAF, THF, $0^{\circ} \mathrm{C}, 1 \mathrm{~h}$, then $r$, overnight; $(f) I B X, D M S O$, THF, rt $6 \mathrm{~h} ;(\mathrm{g})$ $\mathrm{H}_{2} \mathrm{C}=\mathrm{CHCH}_{2} \mathrm{MgBr}, \mathrm{Et}_{2} \mathrm{O}, \mathrm{rt}, 3 \mathrm{~h}$; (h) Candida cylindracea lipase (CCL), $\mathrm{H}_{2} \mathrm{C}=\mathrm{C}\left(\mathrm{CH}_{3}\right) \mathrm{OAc}$, hexane, $\mathrm{rt}, 24 \mathrm{~h}$; (i) DEAD, $\mathrm{PPh}, \mathrm{gl} . \mathrm{AcOH}, \mathrm{THF}, \mathrm{O}^{\circ} \mathrm{C} \rightarrow$ $r t$, overnight ring-closing metathesis of the dienoic ester $\mathbf{5 3}$ (Scheme 10).

The first total synthesis of a solandelactone was recently reported by Davoren and Martin ${ }^{31}$ (Scheme 11). The authors synthesized the solandelactone $\mathrm{E}(\mathbf{4 2})$ and revised the original assignment for $\mathrm{C}_{11}$. Thus, 2,3-O-isopropylidene glyceraldehyde $\mathbf{4 9}$ was converted in the diene $\mathbf{5 3}$, which was selectively dihydroxylated using AD-mix $\beta$ to furnish the diol 54 as a single diastereomer. A thirteen-step sequence of reactions led to the seco acid $\mathbf{5 5}$, which could be submitted to the Yamaguchi lactonization protocol, ${ }^{34}$ followed by TBAF-mediated deprotection of TBS ethers, affording the eight-membered lactone 56. The 1,3transposition of the $\mathrm{C}_{12}$ allylic alcohol could be achieved by treatment of 56 with $o$-nitrophenylselenocyanate and tri- $n$-butylphosphine, leading to the activation and inversion of the less-hindered alcohol to furnish a

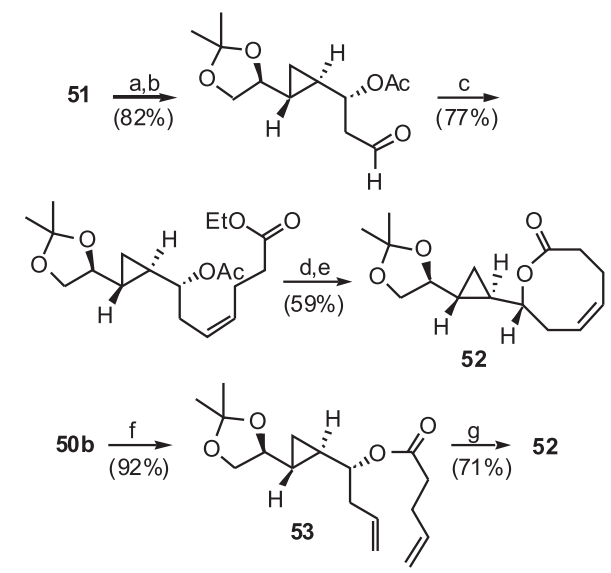

Scheme 10. Reagents and conditions: (a) cat. $\mathrm{OSO}_{4}, \mathrm{NMO}$, acetone; (b) silica gel impregnated with $\mathrm{NaIO}_{4}, \mathrm{CH}_{2} \mathrm{Cl}_{2}$; (c) $\mathrm{BrPh}_{3} \mathrm{PCH}_{2} \mathrm{CH}_{2} \mathrm{CO}_{2} \mathrm{OEt}$, NaHMDS, THF, $78^{\circ} \mathrm{C} \rightarrow r t$; (d) LiOH, MeOH, THF/ $\mathrm{H}_{2} \mathrm{O}, \mathrm{rt}$; (e) 2,4,6-trichlorobenzoyl chloride, $\mathrm{Et}_{3} \mathrm{~N}$, DMAP, toluene, reflux; (f) $\mathrm{H}_{2} \mathrm{C}=\mathrm{CHCH}_{2} \mathrm{CH}_{2} \mathrm{C}(\mathrm{O}) \mathrm{Cl}, \mathrm{Et}_{3} \mathrm{~N}, \mathrm{CH}_{2} \mathrm{Cl}_{2}, \mathrm{O}^{\circ} \mathrm{C} \rightarrow$ $r t ;(g) 2^{\text {nd }}$ generation Grubbs catalyst, $\mathrm{CH}_{2} \mathrm{Cl}_{2}, \mathrm{Ti}(\mathrm{O} \mathrm{Pr})_{4}$, reflux, $50 \mathrm{~h}$ 
selenide, which was converted into the solandelactone E (42) after hydrogen peroxide-mediated oxidation followed by a [2,3]-sigmatropic rearrangement of the intermediate allylic selenoxide.

Recently, White et al..$^{32}$ reported the synthesis of solandelactones $\mathrm{E}$ (42) and F (43) and confirmed the hydroxyl configuration at C11, early revised by Davoren and Martin. ${ }^{31}$ The synthesis starts with an asymmetric aldol reaction between the titanium enolate derived from 58 and the achiral aldehyde 57, followed by cyclopropanation of the Weinreb amide 59 to furnish the cyclopropane intermediate $\mathbf{6 0}$ as a single diastereomer (Scheme 12). Conversion of $\mathbf{6 0}$ to the key cyclic carbonate $\mathbf{6 1}$ was achieved in five steps. Olefination of $\mathbf{6 1}$, followed by a Holmes-Claisen rearrangement of the corresponding ketene acetal, led to the desired eight-membered lactone core of solandelactones $\mathbf{6 2}$. Coupling of $\mathbf{6 3}$ with the acyclic side chain fragment 64 (obtained from $(S$ )-methyl 3,4-dihydroxybutanoate in nine steps) using NHK reaction led to a mixture of $\mathrm{C} 11$ epimeric solandelactones $\mathrm{E}(\mathbf{4 2})$ and $F(\mathbf{4 3})$, in a 3.5:1 ratio, respectively.

\section{Terpenoids}

Some terpenoids bearing an eight-membered ring lactone are described in literature, such as the sesquiterpenes schkuhripinnatolides A-C (65-67), which were isolated from the aerial parts of Schkuhria pinnata collected from Namibia. ${ }^{35}$
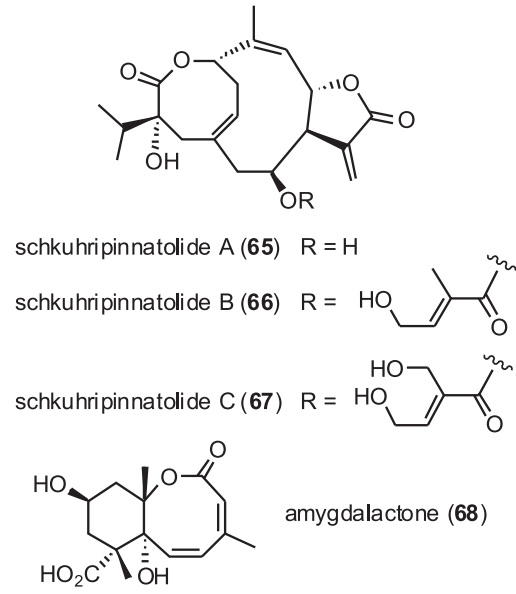

A new unusual sesquiterpene lactone, named amygdalactone (68), was isolated from the hulls of almond (Prunus amygdalus). ${ }^{36}$ Amygdalactone represents a new class of sesquiterpene bearing an octalactone ring system. The cytotoxicity of this compound toward K562, P3HR-1 and CEM leukemia cancer cell lines was evaluated and the results showed very low inhibition rate. There is no synthesis described.<smiles>CCOC(=O)C=C[C@H]1C[C@@H]1[C@H]1COC(C)(C)O1</smiles><smiles>CCOC(=O)C=CC=C[C@H]1C[C@@H]1[C@H]1COC(C)(C)O1</smiles>

53<smiles>[R4]C=CC(=O)OCC=C[C@@H](O)[C@@H](C)[C@H]1C[C@@H]1[C@H]1COC(C)(C)O1</smiles>

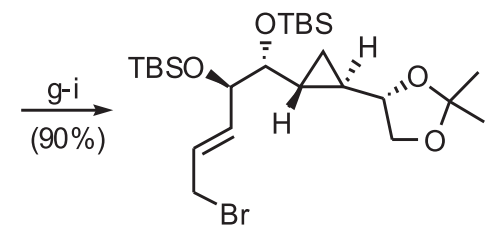

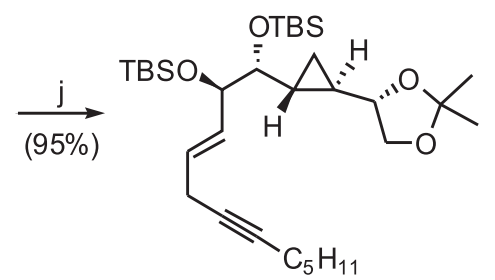<smiles>[Mg][Mg][Mg]</smiles>

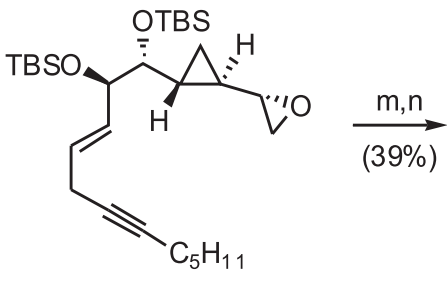

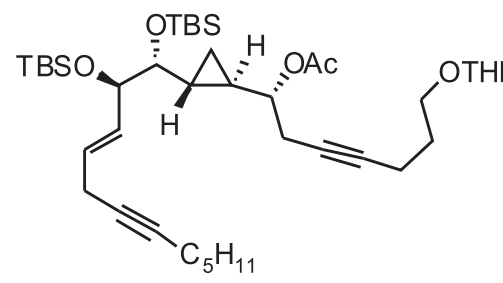

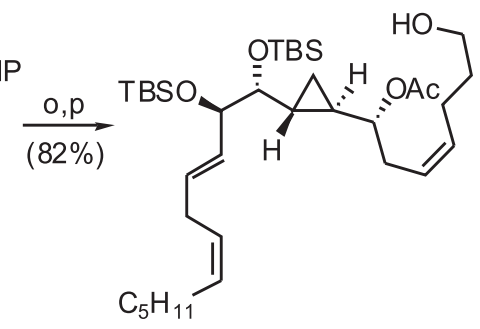

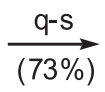

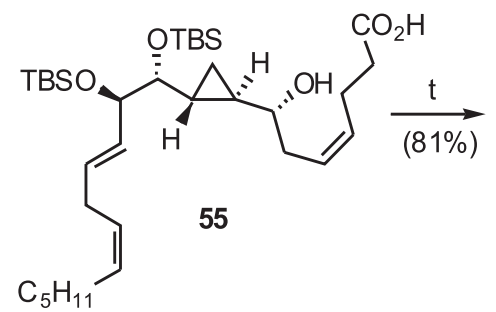

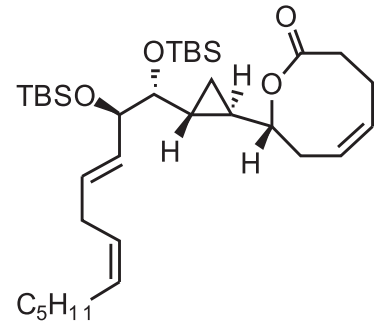<smiles>C=CCCC</smiles>

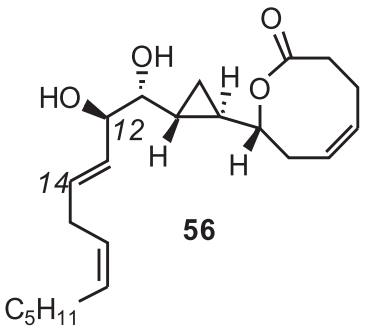<smiles>[X]C(C)(C)C1CCCCC1</smiles>

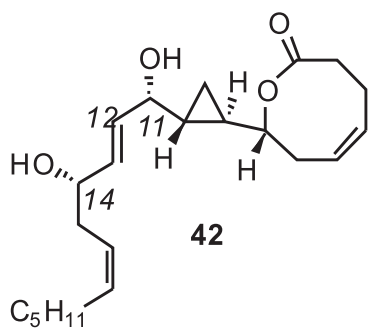

Scheme 11. Reagents and conditions: (a) trans-(EtO) ${ }_{2} \mathrm{P}(\mathrm{O}) \mathrm{CH}_{2} \mathrm{CH}=\mathrm{CHCO}_{2} \mathrm{Et}, \mathrm{LDA}, \mathrm{THF}, \mathrm{O}^{\circ} \mathrm{C}(10 / 1 \mathrm{EE} / \mathrm{EZ}) ;(\mathrm{b}) \mathrm{Et} \mathrm{Zn}_{2} \mathrm{CH}_{2} \mathrm{I}_{2}, 65^{\circ} \mathrm{C}, 4 \mathrm{~h}$ then $5{ }^{\circ} \mathrm{C}, 12 \mathrm{~h}$; (c) DIBAL-H, $\mathrm{CH}_{2} \mathrm{Cl}_{2},-78^{\circ} \mathrm{C}$; (d) TPAP, $\mathrm{NMO}, \mathrm{CH}_{2} \mathrm{Cl}_{2}, \mathrm{rt}$; (e) (EtO) ${ }_{2} \mathrm{P}(\mathrm{O}) \mathrm{CH}_{2} \mathrm{CO}_{2} \mathrm{Et}, \mathrm{NaH}, \mathrm{THF}, \mathrm{O}^{\circ} \mathrm{C}(10: 1 \mathrm{E} / \mathrm{Z}) ;(f) \mathrm{K}_{3} \mathrm{Fe}\left(\mathrm{CN}_{6}\right)_{6} \mathrm{~K}_{2} \mathrm{CO}_{3}, \mathrm{~K}_{2} \mathrm{OsO} \mathrm{O}_{2}(\mathrm{OH})_{4},(\mathrm{DHQD})_{2} \mathrm{PHAL}$, $\mathrm{CH}_{3} \mathrm{SO}_{2} \mathrm{NH}_{2}, \mathrm{t}-\mathrm{BuOH} / \mathrm{H}_{2} \mathrm{O}, \mathrm{rt}$; (g) TBSCl, imidazole, DMF, rt; (h) DIBAL-H, $\mathrm{CH}_{2} \mathrm{Cl}_{2},-78{ }^{\circ} \mathrm{C} \rightarrow \mathrm{rt}$; (i) $\mathrm{CBr}_{4}, \mathrm{PPh}_{3}, \mathrm{CH}_{2} \mathrm{Cl}_{2}, \mathrm{rt}$; (j) n-BuLi, 1-heptyne, CuBr.SMe , $-78{ }^{\circ} \mathrm{C}$; ( $(\mathrm{k}) \mathrm{TFA}, \mathrm{H}_{2} \mathrm{O}, \mathrm{CH}_{2} \mathrm{Cl}_{2}, \mathrm{rt}$; (l) NaH, 1-tosylimidazole, THF, $\mathrm{O}^{\circ} \mathrm{C}$; $(\mathrm{m}) \mathrm{i}: \mathrm{THPO}\left(\mathrm{CH}_{2}\right)_{3} \mathrm{C}^{\circ} \mathrm{CH}, \mathrm{n}$-BuLi, $-78^{\circ} \mathrm{C}, 1 \mathrm{~h}$; ii: $\mathrm{BF}_{3} . \mathrm{OEt}_{2}, \mathrm{THF},-78^{\circ} \mathrm{C}, 45 \mathrm{~min}$, then $100^{\circ} \mathrm{C}, 2 \mathrm{~h}$; (n) $\mathrm{Ac}_{2} \mathrm{O}, \mathrm{DMAP}, \mathrm{Et}_{3} \mathrm{~N}, \mathrm{CH}_{2} \mathrm{Cl}_{2}, \mathrm{rt}, 3.5 \mathrm{~h}$; (o) p-TsOH, i-PrOH, rt; (p) $\mathrm{H}_{2}$, Lindlar catalyst, quinoline, $\mathrm{MeOH}, \mathrm{rt} ;(\mathrm{q}) \mathrm{SO}_{3} . \mathrm{Py}, \mathrm{Et}_{3} \mathrm{~N}, \mathrm{DMSO}, \mathrm{CH} \mathrm{Cl}_{2}$, $r t$; (r) $\mathrm{NaClO}_{2}, \mathrm{NaHPO}_{4}$, 2-methyl-2-butene, $t$-BuOH, $\mathrm{H}_{2} \mathrm{O}, \mathrm{rt}$; (s) $\mathrm{K}_{2} \mathrm{CO}_{3}, \mathrm{MeOH}, \mathrm{rt} ;$ ( $t$ ) 2,4,6-trichlorobenzoyl chloride, Et ${ }_{3} \mathrm{~N}$, DMAP, toluene, reflux; (u) TBAF, $\mathrm{THF}, \mathrm{rt}$; (v) o- $\mathrm{NO}_{2} \mathrm{PhSeCN}, \mathrm{Bu}_{3} \mathrm{P}, \mathrm{THF}, \mathrm{rt}, \mathrm{l}$; $(x) \mathrm{H}_{2} \mathrm{O}_{2}, \mathrm{Py}, \mathrm{CH}_{2} \mathrm{Cl}_{2}, \mathrm{O}^{\circ} \mathrm{C}, 5 \mathrm{~h}$ 


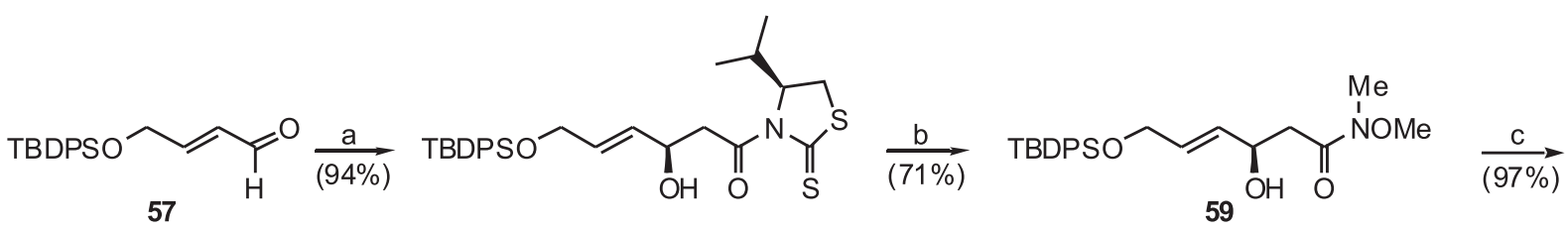

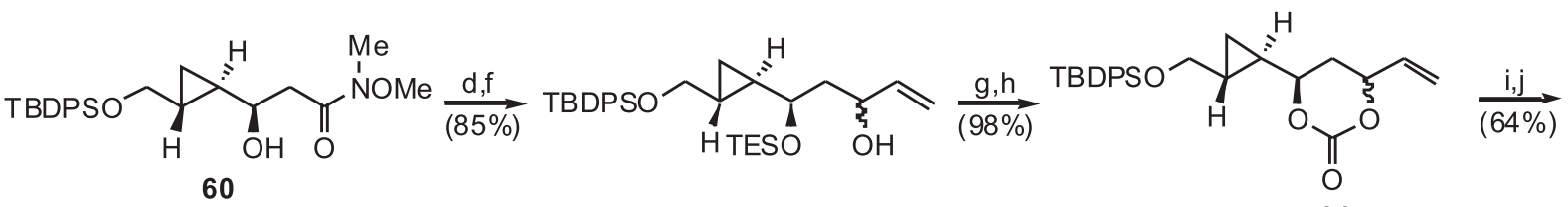

60

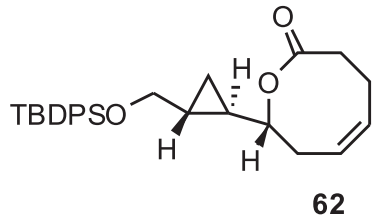

62

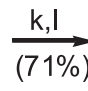

$(71 \%)$

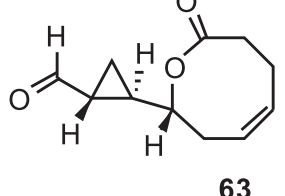

63

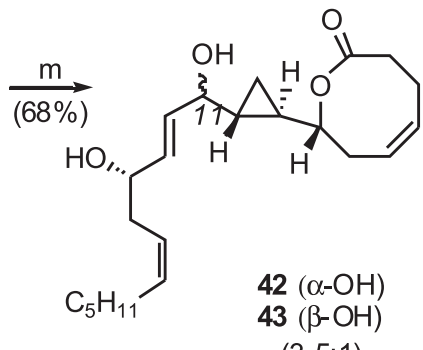

(3.5:1)
61

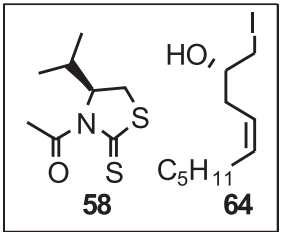

Scheme 12. Reagents and conditions: (a) 1-(4-isopropyl-2-thioxothiazolidin-3-yl)ethanone (58), $\mathrm{TiCl}_{4}, \mathrm{i}-\mathrm{Pr}_{2} \mathrm{NEt}_{1} \mathrm{CH}_{2} \mathrm{Cl}_{2},-78^{\circ} \mathrm{C}, 6 \mathrm{~h}$; (b) $\mathrm{MeONHMe.HCl}$, imidazole, $\mathrm{CH}_{2} \mathrm{Cl}_{2}, \mathrm{rt}, 16 \mathrm{~h}$; (c) Et $\mathrm{Zn}, \mathrm{CH}_{2} \mathrm{I}_{2}, \mathrm{CH}_{2} \mathrm{Cl}_{2},-15^{\circ} \mathrm{C} \rightarrow \mathrm{rt}, 3 \mathrm{~h}$; (d) TESOTf, 2,6-lutidine, $\mathrm{CH}_{2} \mathrm{Cl}_{2}, \mathrm{O}^{\circ} \mathrm{C}, 45 \mathrm{~min}$; (e) DIBAL-H, THF, -78 ${ }^{\circ} \mathrm{C}, 10 \mathrm{~min}$; (f) $\mathrm{H}_{2} \mathrm{C}=\mathrm{CHMgBr}, \mathrm{THF},-78^{\circ} \mathrm{C}, 50 \mathrm{~min} ;(\mathrm{g}) \mathrm{AcOH} / \mathrm{THF} / \mathrm{H}_{2} \mathrm{O}(6 / 2 / 1), \mathrm{rt}, 1 \mathrm{~h} ;(\mathrm{h})\left(\mathrm{Cl}_{3} \mathrm{CO}\right)_{2} \mathrm{CO}, \mathrm{CH}_{2} \mathrm{Cl}_{2}, \mathrm{Et}_{3} \mathrm{~N}, \mathrm{Py}, \mathrm{MS} 4 \mathrm{~A},-78^{\circ} \mathrm{C}, 30 \mathrm{~min}$; (i) Cp $\mathrm{TiMe}_{2}$, toluene, 100 ${ }^{\circ} \mathrm{C}, 2 \mathrm{~h}$ (absence of light); (j) toluene, $100^{\circ} \mathrm{C}$; ( $\mathrm{k}$ ) TBAF, THF, rt, $1 \mathrm{~h}$; (l) TPAP, NMO, $\mathrm{CH}_{2} \mathrm{Cl}_{2}, \mathrm{MS} 4 \mathrm{~A}, \mathrm{rt}, 20 \mathrm{~min}$; ( $\mathrm{m}$ ) $\mathrm{CrCl}_{2}$ (excess), cat. NiCl, DMSO, rt, $18 \mathrm{~h}$

Examples of eight-membered diterpenoid lactones includes the bis-homoditerpenes isoterracinolides A (69) and B (70) (from Euphorbia terracina L.), ${ }^{37}$ and the cembrane diterpenes echinodolides A (71) and B (72), isolated from the Brazilian medicinal plant Echinodorus macrophyllus (also known as "chapéu-decouro"), ${ }^{38}$ used in traditional medicine in the treatment of hepatitis and rheumatism. To our knowledge, there is no report concerning the synthesis and the biological activities of these compounds.

Astakolactin (73) is a sesterterpene isolated in 2003 from the mediterranean sponge Cacospongia scalaris. ${ }^{39}$ To our knowledge, neither biological tests nor synthetic studies for this metabolite are reported.

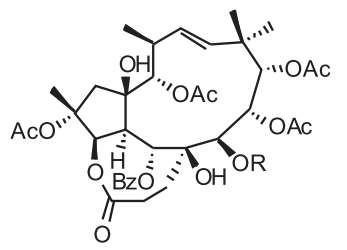

isoterracinolide $A(69)\left(R=C^{\prime} \mathrm{Pr}\right)$ isoterracinolide $B(\mathbf{7 0})(R=C O E t)$

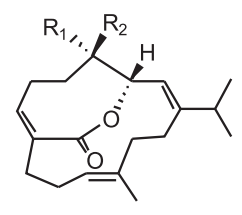

echinodolide $A$ (71) $\left(\mathrm{R}_{1}=\mathrm{Me}, \mathrm{R}_{2}=\mathrm{OH}\right)$ echinodolide $B(72)\left(R_{1}=O H, R_{2}=M e\right)$

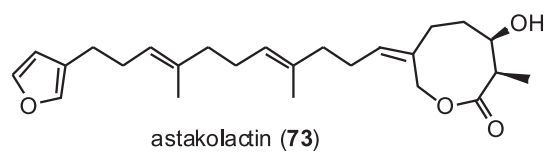

\section{Dimeric lactones}

Recently, Dat et al..$^{40}$ isolated the dimeric lactones ardimerin (74) and ardimerin digallate (75) from the extracts of Ardisia japonica, a plant used in Oriental traditional medicine as antitussive and diuretic, as well as to stop uterine bleeding. The diolide $\mathbf{7 5}$ showed in vitro inhibitory effect of HIV-1 and HIV-2 RNase H $\left(\mathrm{IC}_{50}\right.$ of 1.5 and $1.1 \mu \mathrm{M}$, respectively).<smiles>[R]CC(C)C1CC(O)C(O)C(O)C1O</smiles>

\section{Revised structures}

The structures of some natural products early identified as being eight-membered rings were revised later. Thus, the initially proposed structures for puerosides $\mathrm{A}$ and $\mathrm{B}^{41}$, sophoroside $\mathrm{A}^{42}$ and speciosides $\mathrm{A}$ and $\mathrm{B}^{43}$ were showed to be butenolides (Table 1). ${ }^{44}$

Table 1. Revised structures for puerosides A and B, sophoroside A and speciosides $\mathrm{A}$ and $\mathrm{B}^{43}$

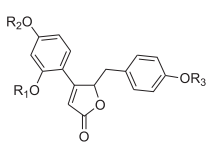

\begin{tabular}{lccc}
\hline Lactone & $\mathrm{R}_{1}$ & $\mathrm{R}_{2}$ & $\mathrm{R}_{3}$ \\
\hline (-)-pueroside A & glu $^{6}$-rha & $\mathrm{H}$ & $\mathrm{H}$ \\
(-)-pueroside B & $\mathrm{glu}$ & $\mathrm{Me}$ & glu \\
(+)-sophoroside A & $\mathrm{glu}$ & $\mathrm{Me}$ & $\mathrm{H}$ \\
specioside A & $\mathrm{glu}$ & $\mathrm{H}$ & $\mathrm{H}$ \\
specioside B & $\mathrm{H}$ & $\mathrm{glu}$ & $\mathrm{H}$ \\
\hline
\end{tabular}

glu = glucose; rha $=$ rhamnose . 
Similarly, the structures of gonioheptolides A (76) and B (77), isolated in 1993 from the stem bark of Goniothalamus giganteus, ${ }^{45}$ were corrected some years later. ${ }^{46}$ Independently, Bermejo et al. ${ }^{47}$ have isolated from Goniothalamus arvensis two compounds with spectroscopic data very similar to those observed for the gonioheptolides, and called them almuheptolide A (78) and B (79). These metabolites have been cited in some other papers, ${ }^{48,49}$ up to 2002, when a revision of the structure of $\mathbf{7 8}$ was also reported. ${ }^{50,51}$

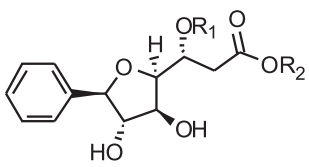

gonioheptolide A (76) $\left(\mathrm{R}_{1}=\mathrm{H} ; \mathrm{R}_{2}=\mathrm{Me}\right)$ gonioheptolide $B(77)\left(R_{1}=H ; R_{2}=E t\right)$ almuheptolide $A(78)\left(R_{1}=R_{2}=M e\right)$

\section{NINE-MEMBERED RING LACTONES}

\section{Halicholactone and neohalicholactone}

The eicosanoid oxylipins (-)-halicholactone (80) and (-)neohalicholactone $(\mathbf{8 1})$ were isolated from the marine sponge Halichondria okadai (Kadota) collected at Daiozaki, Japan. Halicholactone (80) exhibited weak inhibitory activity against lipoxygenase of guinea pig polymorphonuclear leukocytes. ${ }^{52}$

In 1991, the relative stereochemistry of all stereocenters of neohalicholactone $\mathbf{( 8 1}$ ) has been determined by X-ray crystallography as shown below. ${ }^{53}$ Some years later, Proteau et al..$^{54}$ isolated $\mathbf{8 1}$ from the brown alga Laminaria sinclairii, and its absolute configuration was suggested to be the opposite to that previously postulated.

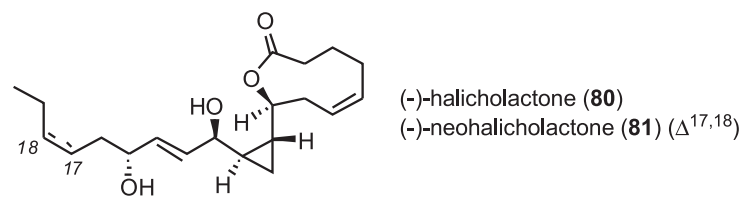

The three total syntheses ${ }^{55-57}$ of halicholactone $(\mathbf{8 0})$ and neohalicholactone $(\mathbf{8 1})$ reported in literature will be briefly presented here, since Shiina ${ }^{5}$ discussed them in details in his review. A formal synthesis of $\mathbf{8 0}$ and $\mathbf{8 1}$ was described in $1998 .{ }^{58}$

Critcher et al. reported the synthesis of the right-hand hemisphere ${ }^{59}$ and the first asymmetric total synthesis of halicholactone $(\mathbf{8 0})$ and neohalicholactone $(\mathbf{8 1}),{ }^{55}$ confirming the original assignments of absolute configuration of the stereocenters of $\mathbf{8 1}$ originally proposed by Yamada and Clardy. ${ }^{53}$ They also demonstrated, through the preparation of diastereomers of $\mathbf{8 1},{ }^{55}$ that the natural product isolated by Proteau et al. ${ }^{54}$ was, in fact, a C15 epimer of this nine-membered lactone.

The synthetic strategy was based on the preparation of the key intermediate 83. The lactonization of seco acid $\mathbf{8 2}$, using the Yamaguchi protocol, ${ }^{34}$ led to the nine-membered ring lactone $\mathbf{8 3}$, which could be transformed into (-)-halicholactone (80) and (-)neohalicholactone (81) in six additional steps (Scheme 13).

The others two synthetic approaches to (-)-halicholactone (80) were reported by Takemoto et al..$^{56}$ and Takahashi et al..$^{57}$ The authors used as key step the ring-closing metathesis of dienoic ester 84, using first generation Grubbs catalyst and titanium isopropoxyde as Lewis acid, to achieve the nine-membered lactone $\mathbf{8 5}$, which could be converted into (-)-80 by hydrolysis of the acetyl protecting groups (Scheme 14).

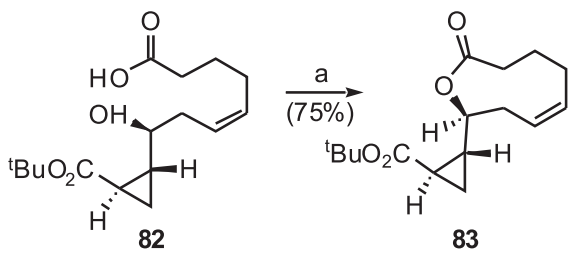

Scheme 13. Reagents and conditions: (a) i: 2,4,6-trichorobenzoyl chloride, THF, rt, 2 h; ii: DMAP, toluene, reflux, $6 \mathrm{~h}$

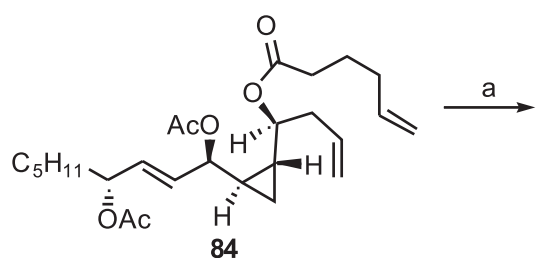

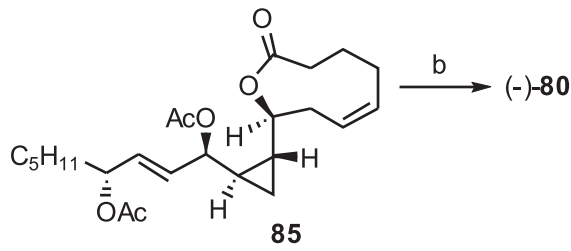

Scheme 14. Reagents and conditions: (a) $1^{\text {st }}$ generation Grubbs catalyst, Ti(Oi$\mathrm{Pr})_{4} \mathrm{CH}_{2} \mathrm{Cl}_{2}(0.1 \mathrm{mM})$, reflux, (72\% in ref. 56 and $93 \%$ in ref. 57); (b) $\mathrm{K}_{2} \mathrm{CO}_{3}$, $\mathrm{MeOH}, \mathrm{rt}(61 \%$ in ref. 56 and $55 \%$ in ref. 57)

\section{Topsentolides}

Topsentolides $\mathrm{A}_{1}, \mathrm{~A}_{2}, \mathrm{~B}_{1}, \mathrm{~B}_{2}, \mathrm{~B}_{3}, \mathrm{C}_{1}$, and $\mathrm{C}_{2}$ (86-92) are oxylipins isolated in 2006 from the marine sponge Topsentia $s p .{ }^{60}$ These lactones exhibit moderate citotoxicity against human solid tumor cell lines. According to the authors, the (+)-topsentolide $\mathrm{C}_{1}(\mathbf{9 1})$ and (+)-topsentolide $\mathrm{C}_{2}(\mathbf{9 2})$ are suspected to be artefacts formed during the extraction with methanol. Synthetic approaches to these nine-membered lactones were not found in the literature.
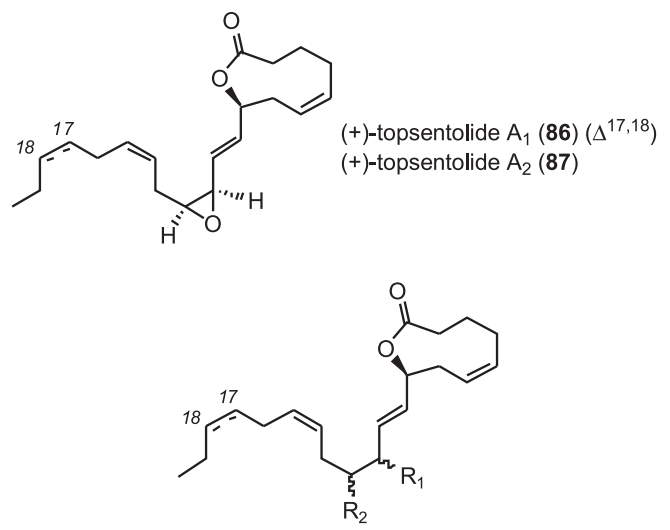

(+)-topsentolide $\mathrm{B}_{1}(\mathbf{8 8})\left(\mathrm{R}_{1}=\beta-\mathrm{OH} ; \mathrm{R}_{2}=\alpha-\mathrm{OH} ; \Delta^{17,18}\right)$

(+)-topsentolide $B_{2}(89)\left(R_{1}=\beta-O H ; R_{2}=\alpha-O H\right)$

(+)-topsentolide $\mathrm{B}_{3}(\mathbf{9 0})\left(\mathrm{R}_{1}=\beta-\mathrm{OH} ; \mathrm{R}_{2}=\beta-\mathrm{OH}\right)$

(+)-topsentolide $\mathrm{C}_{1}(91)\left(\mathrm{R}_{1}=\mathrm{OCH}_{3} ; \mathrm{R}_{2}=\beta-\mathrm{OH} ; \Delta^{17,18}\right)$

(+)-topsentolide $\mathrm{C}_{2}(92)\left(\mathrm{R}_{1}=\mathrm{OCH}_{3} ; \mathrm{R}_{2}=\beta-\mathrm{OH}\right)$

\section{Terpenoids}

Isotrichogoniolide $(\mathbf{9 3})^{61}$ and $(+)$-sinulariadiolide $(\mathbf{9 4})^{62}$ are ninemembered terpenoid lactones, isolated from Trichogonia $s p$ and from a coral of the genus Sinularia, respectively, and were not synthesized yet. 


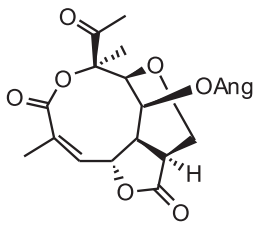

isotrichogoniolide (93)

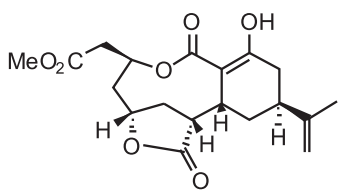

$(+)$-sinulariadiolide (94)

\section{Antimycins}

The antimycin-A antibiotics are a series of nine-membered dilactones, which were isolated from a number of Streptomyces strains over many decades. ${ }^{63}$ A complex mixture of antimycins $\mathrm{A}_{1}-\mathrm{A}_{8}$ is a specific inhibitor of the electron transfer activity of ubiquinolcytochrome $c$ oxidoreductase. ${ }^{64}$ The antimicyns have also other biological properties such as antifungal activity, inhibition of enzymatic activity as well as the ability to induce the death of cancer cells. ${ }^{65}$

The main component of this family of peptide alkaloids is the antimycin $\mathrm{A}_{3}$, which had been considered as an unique compound until 1988, when analytical investigations using HPLC techniques revealed that this natural product is, in fact, a mixture of the antimycins (+)- $\mathrm{A}_{3 \mathrm{a}}(\mathbf{9 5})$ and (+)- $\mathrm{A}_{3 \mathrm{~b}}(96) .{ }^{66}$ The slight difference between these two nine-membered dilactones relied upon the ester function at C8: (+)-95 is a sec-butyl ester while the (+)-96 is the isobutyl analog.

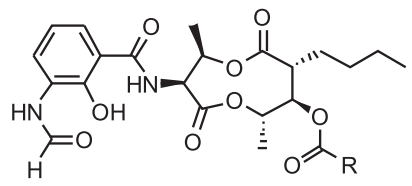

(+)-antimycin $\mathrm{A}_{3 a}(95) \quad \mathrm{R}=$ sec-buty (+)-antimycin $A_{3 b}(96) \quad R=$ isobutyl

Both racemic ${ }^{67}$ and stereoselective synthesis ${ }^{68}$ of natural (+)antimycins $\mathrm{A}_{3 \mathrm{~b}}$ (96) have been first accomplished by Kinoshita et al. Tsunoda group developed an asymmetric aza-Claisen rearrangement of enolates of carboxamides and applied this methodology to the synthesis of both, unnatural (-)-antimycin $\mathrm{A}_{3 \mathrm{~b}}{ }^{69}$ (ent-96) and natural (+)-antimycin $\mathrm{A}_{3 \mathrm{a}}{ }^{70}(\mathbf{9 5})$, while one approach for (+)-antimycin $A_{3 \mathrm{~b}}$ (125) was recently reported. ${ }^{71}$ Some formal synthesis of these dilactones are also found in the literature. ${ }^{72}$

Kinoshita et al. ${ }^{68}$ reported the first asymmetric total synthesis of (+)-antimycin $\mathrm{A}_{3 \mathrm{~b}}$ (96) as well as the synthesis of one of its diastereomers. Lactonization of (+)-( $3 S, 4 R, 7 R, 8 R, 9 S)$-hydroxyacid 97a afforded the nine membered dilactone 98 in only $c a$. $1 \%$ yield. A sequence of reactions on the amino group at the $\mathrm{C} 3$ position led to the desired natural (+)-96 (Scheme 15).

Similarly, the authors could prepare the unnatural diastereomer (-)-(3S,4R,7S,8S,9R)-100 of (+)-antimycins $\mathrm{A}_{3 \mathrm{~b}}$, starting from the hydroxyacid 97b (Scheme 16), following the same sequence of reactions outlined in Scheme $15 .{ }^{68}$

The synthesis of unnatural (-)-antimycin $\mathrm{A}_{3 \mathrm{~b}}$ (ent-96) reported by Tsunoda et al. $^{69}$ started from $(R)-(+)$-methylbenzylamine, which was transformed in the amide $\mathbf{1 0 1}$ in three steps. The aza-Claisen rearrangement of $\mathbf{1 0 1}$ led the expected amide as a mixture of four stereoisomers, from which the main isomers $102 \mathbf{a}$ and $\mathbf{1 0 2} \mathbf{b}$ could be obtained as a unseparable 4:1 mixture, respectively. Iodolactonization of $\mathbf{1 0 2} \mathbf{a} / \mathbf{1 0 2} \mathbf{b}$, followed by reduction with $n$ $\mathrm{Bu}_{3} \mathrm{SnH}$, afforded the lactones $\mathbf{1 0 3 a} / \mathbf{1 0 3} \mathbf{b}$, which was converted into the desired prenyl ester 104a/104b along with the butenolide by-product $\mathbf{1 0 5}$. Mitsunobu reaction ${ }^{73}$ of $\mathbf{1 0 4 a / 1 0 4 b}$ with $N, O$ protected $D$-threonine (106) led to a mixture of the diesters 107a and $\mathbf{1 0 7 b}$. Hydrolysis of TBDMS and prenyl protecting groups was easily achieved to furnish the seco acids $\mathbf{1 0 8 a} / \mathbf{1 0 8 b}$, which was
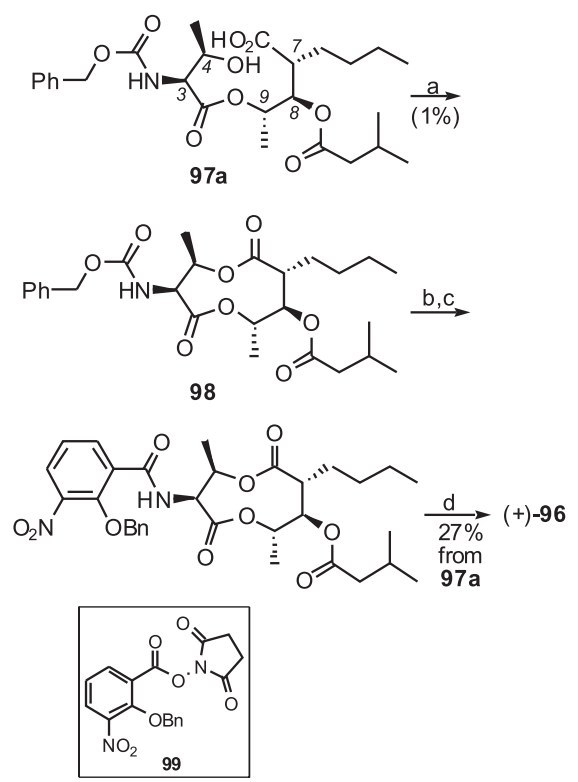

Scheme 15. Reagents and conditions: (a) $i$ : TFA, rt, 10 min; ii: TTFA, benzene, 65-70 ${ }^{\circ} \mathrm{C}, 6 \mathrm{~h}$; (b) palladium black, $\mathrm{H}_{2}, \mathrm{MeOH}, \mathrm{rt}, 35 \mathrm{~min}$; (c) i: O-benzyl-3nitrosalicylic acid $N$-hydroxysuccinimide ester (99), $\mathrm{THF}, 36^{\circ} \mathrm{C}, 3 \mathrm{~h} ; \mathrm{ii}^{\mathrm{E}} \mathrm{Et}_{3} \mathrm{~N}$ (pH=6), $36{ }^{\circ} \mathrm{C}, 25 \mathrm{~h}$; (d) i: palladium black, $\mathrm{H}_{2}, \mathrm{MeOH}, \mathrm{rt}, 10 \mathrm{~min}$; ii: dicyclohexylcarbodiimide (DCCI), $\mathrm{THF}, \mathrm{HCO}_{2} \mathrm{H}, \mathrm{O}^{\circ} \mathrm{C}, 4 \mathrm{~h}$

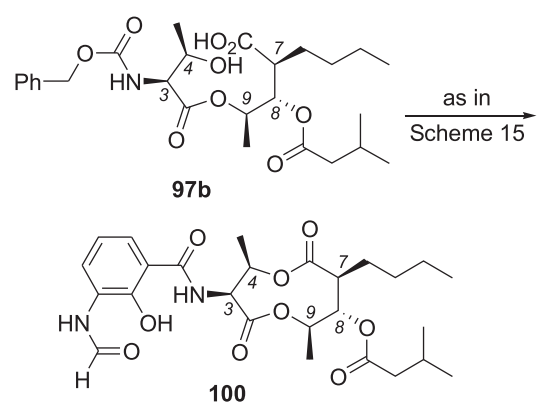

Scheme 16

submitted to the Corey-Nicolaou lactonization ${ }^{14}$ to afforded a separable mixture of the nine-membered dilactones $\mathbf{1 0 9} \mathbf{a} / \mathbf{1 0 9 b}$. The unnatural (-)-antimycin $\mathrm{A}_{3 \mathrm{~b}}$ (ent-96) could then be obtained from 109a, after five additional steps (Scheme 17).

In $2003,{ }^{70}$ the same Japanese group reported the stereoselective synthesis of (+)-antimicym $\mathrm{A}_{3 \mathrm{a}}(\mathbf{9 5})$ and established the absolute configuration at the $\mathrm{C}^{\prime}$ position on the acyloxy side chain. The authors used (S)-(-)-methylbenzylamine for the preparation of the seco acids $\mathbf{1 0 8}$ /108d, following the same sequence of reactions early used for the synthesis of unnatural ent-96. ${ }^{69}$ Corey-Nicolaou lactonization ${ }^{14}$ of $\mathbf{1 0 8} / \mathbf{1 0 8 d}$, using $\mathrm{Cu}(\mathrm{OTf})_{2} . \mathrm{PhH}$ complex instead the explosive $\mathrm{AgClO}_{4}$ metal salt, afforded a separable mixture of the nine-memebered dilactones $\mathbf{1 0 9} \mathbf{c} / \mathbf{1 0 9 d}$ in $88 \%$ yield. Removal of the TIPS-protecting group, followed by esterification of the free hydroxyl group of 109c with $(S)$ - and $(R)$-2-methylbutanoic acid allowed the establishment of the $S$-configuration at the $\mathrm{C}^{\prime}$ ' position in the natural (+)-95 (Scheme 18).

More recently, Wu and Yang ${ }^{71}$ synthesized the (+)-antimycin $\mathrm{A}_{3 \mathrm{~b}}$ (96) using a $\mathrm{TiCl}_{4}$-mediated asymmetric aldolization to construct the $\mathrm{C} 7 / \mathrm{C} 8$ stereocenters in $\mathbf{1 1 1}$ with the correct configurations. A lactonization method ${ }^{74}$ based on the activation of the acyl group through the formation of w-hydroxyacid $\mathbf{1 1 2}$ (via the formation of 


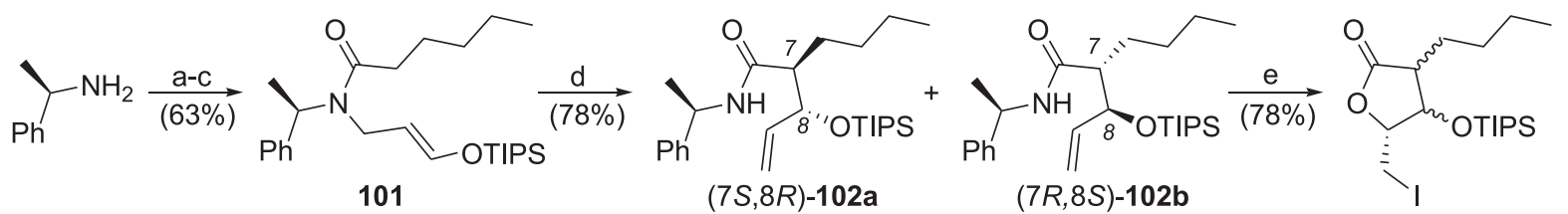

(4:1 mixture)

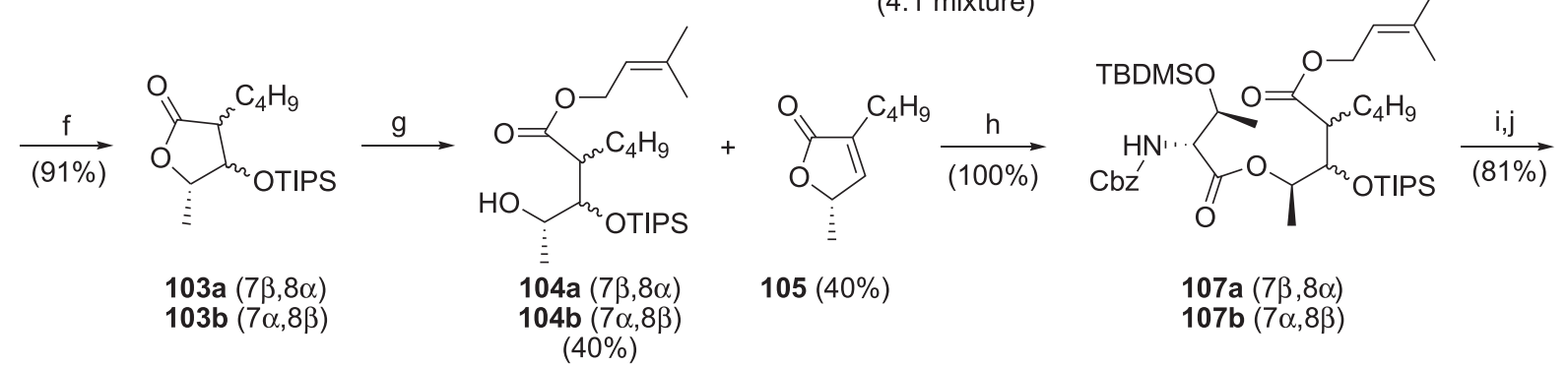

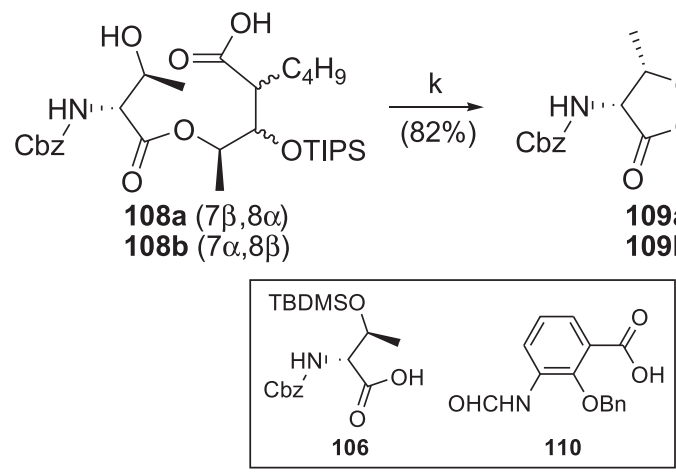

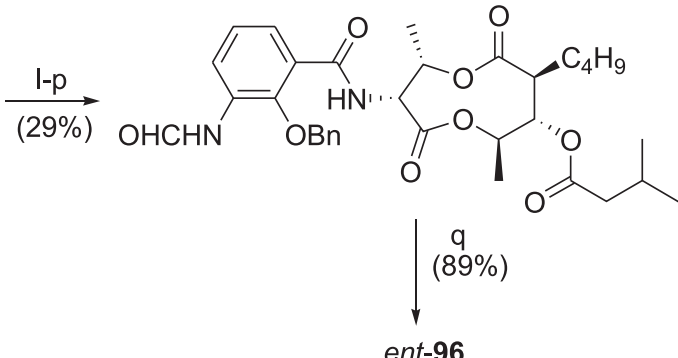

Scheme 17. Reagents and conditions: (a) TMSOTf, DBU, ether, $\mathrm{O}^{\circ} \mathrm{C}, \mathrm{Ih}$; (b) TIPSOTf, acrolein, $\mathrm{O}^{\circ} \mathrm{C}$ ' $\rightarrow \mathrm{rt}, 6 \mathrm{~h}$; (c) $\mathrm{CH}_{3} \mathrm{CH}_{2} \mathrm{CH}_{2} \mathrm{CH}_{2} \mathrm{CH}_{2} \mathrm{C}(\mathrm{O}) \mathrm{Cl}_{1} \mathrm{Et}_{3} \mathrm{~N}$, $\mathrm{CH}_{2} \mathrm{Cl}$, $0^{\circ} \mathrm{C}$; (d) i: LHMDS, toluene, $-78^{\circ} \mathrm{C}$; ii: $120^{\circ} \mathrm{C}, 6 \mathrm{~h}$; (e) $\mathrm{I}_{2}, \mathrm{~N}, \mathrm{~N}$-dimethyl-p-nitroaniline, DME/ $\mathrm{H}_{2} \mathrm{O}(3 / 2), r t, 3$ days; ( $f$ ) Bu $\mathrm{Su}_{3} \mathrm{SnH}$, benzene, reflux; $(\mathrm{g}) \mathrm{i}$ : CsOH, $t$ $\mathrm{BuOH}, \mathrm{O}^{\circ} \mathrm{C}$; ii: prenyl bromide, Py, ether, $0^{\circ} \mathrm{C}, 24 \mathrm{~h}$, (h) 106, DEAD, PPh, benzene, rt, $24 \mathrm{~h}$; (i) $6 \mathrm{Naq}$. HCl, EtOH, rt, $24 \mathrm{~h} ;(\mathrm{j}) \mathrm{Pd}(\mathrm{OAc})_{2}, \mathrm{PPh}, \mathrm{Et}_{3} \mathrm{~N}, \mathrm{HCO} \mathrm{H}_{2} \mathrm{H}$, dioxane, $100^{\circ} \mathrm{C}, 1 \mathrm{~h}$; ( $\mathrm{k}$ ) i: pySSpy, $\mathrm{PPh}$, benzene, $r \mathrm{r}, 3 \mathrm{~h}$; ii: $\mathrm{AgClO}_{4}$, benzene, $80^{\circ} \mathrm{C}, 2 \mathrm{~h}$; (l) chromatographic separation (isolation of 109a); ( $\mathrm{m}$ ) TBAF, THF, $0^{\circ} \mathrm{C}$, 5 min; ( $n$ ) isovaleric anhydride, Py; (o) $\mathrm{H}_{2}, \mathrm{Pd} / \mathrm{C}$, AcOEt; ( $)$ ) 110, water-soluble carbodiimide (WSC), 1-hydroxybenzotriazole (HOBt), $N$-methylmorpholine (NMM), DMF, rt; (q) $\mathrm{H}_{2}, \mathrm{Pd} / \mathrm{C}, \mathrm{AcOEt}$

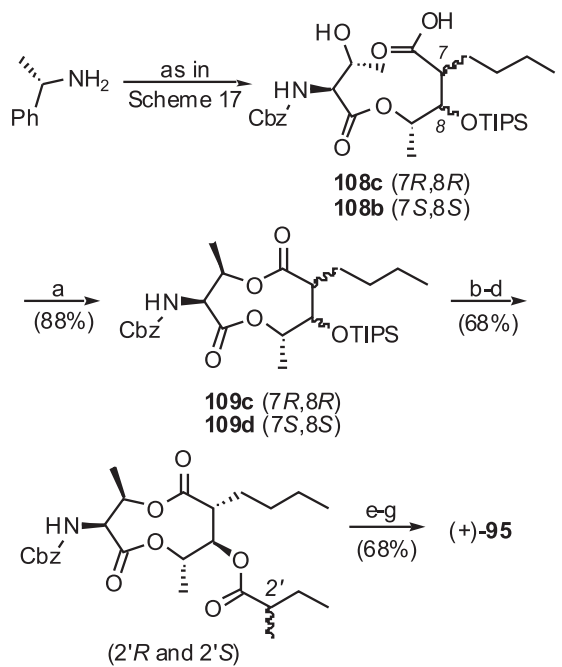

Scheme 18. Reagents and conditions: (a) i: pySSpy, PPh, benzene, $3 \mathrm{~h}$; ii: $\mathrm{Cu}(\mathrm{OTf})_{2} . \mathrm{PhH}$, benzene, $80^{\circ} \mathrm{C}, 3 \mathrm{~h} ;(\mathrm{b})$ chromatographic separation (isolation of 109c); (c) HF.Py, THF, $23 \mathrm{~h}$; (d) (S)- and (R)-2-methylbutanoic acid, WSC, DMAP, $\mathrm{CH}_{2} \mathrm{Cl}_{2}$; (e) $\mathrm{H}_{2}, \mathrm{Pd} / \mathrm{C}$, AcOEt; (f) 110, WSC, HOBt, NMM, DMF, rt; (q) $\mathrm{H}_{2}, \mathrm{Pd} / \mathrm{C}, \mathrm{AcOEt}$

a mixed anhydride after treatment with 2-methyl-6-nitrobenzoic anhydride, MNBA), was used to construct the nine-membered dilactone moiety (Scheme 19).

\section{Griseoviridin}

The macrocyclic peptide (-)-griseoviridin (115), isolated from Streptomyces griseus, is a broad-spectrum antibiotic, with inhibitory activity toward various pathogenic bacteria and fungi. ${ }^{75,76}$ This alkaloid contains, among other functionalities, an unsaturated ninemembered thioether-lactone subunit.<smiles>C[C@H](NC(=O)c1coc(CC(O)C[C@@H](O)/C=C/C=C\CNC(=O)C2=CC[C@@H](C)SC2)n1)C(=O)O</smiles>

(-)-griseoviridin (115)

Several synthetic approaches to the sulfur-containing lactone moiety of griseoviridin have been reported, ${ }^{77}$ and a total synthesis of (-)-griseoviridin (115) was accomplished by Dvorak et al. ${ }^{78}$ in 2000 (Scheme 20). The authors used the RCM of 118, followed by acid removal of the diol protecting group, to obtain the macrocycle (-)-115 as a single diastereomer. It is noteworthy that the lactonization of $\omega$-hydroxyacid $\mathbf{1 1 6}$ to the nine-membered lactone intermediate $\mathbf{1 1 7}$ (with inversion of the configuration of C5) was easily achieved using the Mistunobu protocol. ${ }^{73}$ 


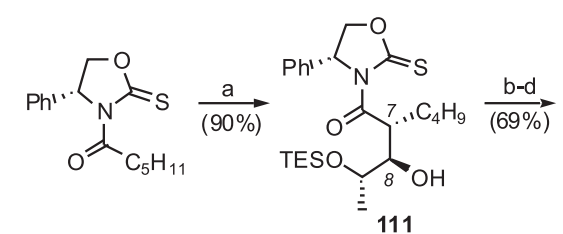<smiles>CC(C)CC(=O)OC([C@@H](C)O)[C@@H](CC(C)C)OC(=O)CC(C)C</smiles>

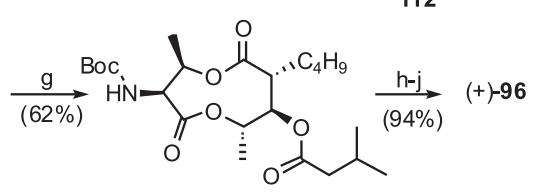<smiles>CC(C)C(=O)CCCC(C)C(N)C(=O)O</smiles>

Scheme 19. Reagents and conditions: (a) $\mathrm{i}: \mathrm{TiCl}_{4}, \mathrm{TMEDA}, \mathrm{CH}_{2} \mathrm{Cl}_{2},-50^{\circ} \mathrm{C}, 20$ min, then $-20{ }^{\circ} \mathrm{C}, 2 \mathrm{~h}$; ii: TMEDA, $-20^{\circ} \mathrm{C}, 1 \mathrm{~h}$; iii: TES-protected (S)-2hydroxypropanal (113), $-20^{\circ} \mathrm{C}, 2 \mathrm{~h}$, then $-5{ }^{\circ} \mathrm{C}, 6 \mathrm{~h}$; (b) $\mathrm{Me}_{2} \mathrm{CHCH}_{2} \mathrm{C}(\mathrm{O}) \mathrm{Cl}$, $\mathrm{Py}, \mathrm{DMAP}, \mathrm{CH}_{2} \mathrm{Cl}_{2}, \mathrm{O}^{\circ} \mathrm{C}, 8 \mathrm{~h}$; (c) BnOH, DMAP, $\mathrm{CH}_{2} \mathrm{Cl}_{2}, \mathrm{rt}, 32 \mathrm{~h}$; (d) $\mathrm{NaIO}_{4}$, THF/ $\mathrm{H}_{2} \mathrm{O}(3 / 1), \mathrm{O}^{\circ} \mathrm{C}, 3 \mathrm{~h}$; (e) i: 114, $\mathrm{DCC}, \mathrm{CH}_{2} \mathrm{Cl}_{2}, \mathrm{O}^{\circ} \mathrm{C}, 50 \mathrm{~min}$; ii: DMAP, rt, $26 \mathrm{~h}$; (f) $\mathrm{H}_{2}$ (30 atm), $\mathrm{Pd}(\mathrm{OH})_{2} / \mathrm{C}, \mathrm{MeOH}, 40{ }^{\circ} \mathrm{C}, 8 \mathrm{~h} ;(\mathrm{g}) \mathrm{MNBA}, \mathrm{DMAP}$, toluene, $\mathrm{MS} 4 \mathrm{~A}, \mathrm{rt}, 23 \mathrm{~h}$; (h) TFA, $\mathrm{CH}_{2} \mathrm{Cl}_{2}, 20{ }^{\circ} \mathrm{C}, 9.5 \mathrm{~h}$; (i) 110, 1-(3dimethylaminopropyl)-3-ethylcarbodiimide hydrochloride (EDC.HCl), $\mathrm{HOBt}$, NMM, DMF, $30^{\circ} \mathrm{C}, 23 \mathrm{~h}$; (i) $\mathrm{H}_{2}, 10 \% \mathrm{Pd} / \mathrm{C}, \mathrm{EtOAc}, 30^{\circ} \mathrm{C}, 6.5 \mathrm{~h}$
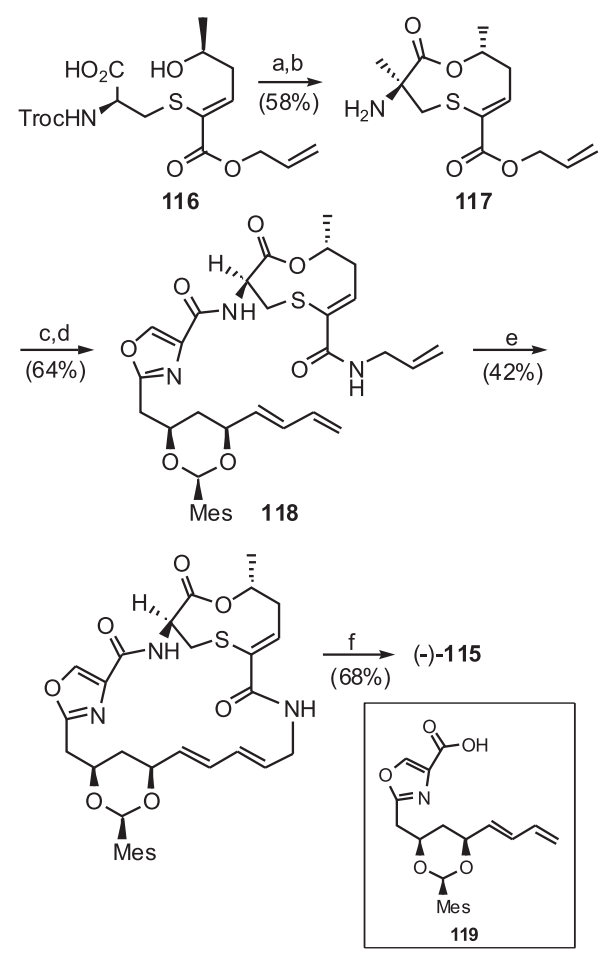

Scheme 20. Reagents and conditions: (a) DIAD, $P P h_{3}, T H F$; (b) $10 \% \mathrm{Cd} / \mathrm{Pb}$, $1 \mathrm{MNH}{ }_{4} \mathrm{OAc}$, THF; (c) 119, $N^{\prime}$-(3-dimethylaminopropyl)-N-ethylcarbodiimide (EDCI), HOBt, DMF; (d) $\mathrm{Pd}\left(\mathrm{PPh}_{3}\right)_{4}$, pyrrolidine, $\mathrm{H}_{2} \mathrm{C}=\mathrm{CHCH}_{2} \mathrm{NH}_{2}, \mathrm{HOBt}$, EDCI, DMF; (e) $1^{\text {st }}$ generation Grubbs catalyst, toluene $(0,001 \mathrm{M}), 100{ }^{\circ} \mathrm{C}$; (f) pyridinium-p-toluenesulfonate (PPTS), acetone $/ \mathrm{H}_{2} \mathrm{O}$

\section{Revised structures}

In 1993, Cutler et al. ${ }^{79}$ isolated a bioactive product from a strain of the fungus Botrytis cinerea and named it botcinolide. The structure of this compound was determined as being a polyhydroxylated ninemembered ring lactone (120a, Figure 1).$^{80} \mathrm{~A}$ homologue of botcinolide, called homobotcinolide (121a), was isolated by these authors in $1996 .{ }^{81}$ The isolation of other botcinolide derivatives was also reported by Collado et al. ${ }^{82,83}$<smiles>[R]C(O)/C=C/C1O[C@@H]2OC(=O)[C@H](C)[C@@H](O)[C@H](O)[C@H](C)[C@H]2O1</smiles>

proposed structures:

botcinolide (120a) $\left(\mathrm{R}=n-\mathrm{C}_{4} \mathrm{H}_{9}\right)$

homobotcinolide (121a) $\left(\mathrm{R}=n-\mathrm{C}_{6} \mathrm{H}_{13}\right)$<smiles>[R]C(O)/C=C/C(=O)O[C@@H]1[C@H](C)O[C@@](O)([C@H](O)[C@H](C)O)[C@@H](O)[C@@H]1C</smiles>

revised structures:

botcinolide (seco-acid of botnicin $\mathrm{E}$ ) (botcinic acid, 120b) $\left(\mathrm{R}=n-\mathrm{C}_{4} \mathrm{H}_{9}\right)$

homobotcinolide (botcineric acid, 121b) $\left(\mathrm{R}=n-\mathrm{C}_{6} \mathrm{H}_{13}\right)$

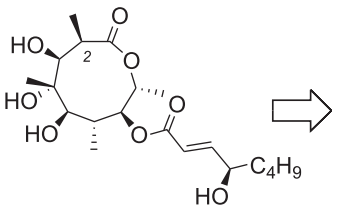
of 2-epibotcinolide (122a) proposed structure

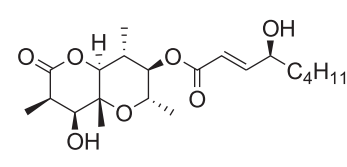

revised structure of 2-epibotcinolide (botcinin E, 122b)
Figure 1. Botcinolide and analogues

Tani et al. ${ }^{84}$ reinvestigated the spectroscopic data reported for botcinolide and some derivatives, and revised their structures (Figure 1). They found that botcinolide, originally reported as the ninemembered lactone 120a, is in fact the seco acid of botnicin E, as well as the structure of 2-epibotcinolide (122a) was revised as being the same as that of botcinin E (122b). In addition, botcinolide was renamed botcinic acid (120b) and the name of homobotcinolide was also changed to botcineric acid (121b).

An approach toward the synthesis of the lactone moiety of the unnatural pseudo 2-epi-8-epibotcinolide was reported by Chakraborty and Goswami. ${ }^{85}$

Independently, Shiina et al. ${ }^{86}$ recently achieved the total synthesis of the pseudo 2-epibotcinolide (122a) and showed that the proposed structures for this compound and related ones are doubtful. The authors prepared the nine-membered lactone core $\mathbf{1 2 4}$ through the lactonization of seco acid 123 using MNBA as activating reagent (Scheme 21). Epimerization of C2 in $\mathbf{1 2 5}$ smoothly took place on silica gel to afford the 2-epi-125 in $82 \%$ yield. Deprotection of the diol at C4-C5 led to the unstable pseudo 2-epibotcinolide (122a), which underwent facile translactonization to the corresponding $\gamma$-lactone $\mathbf{1 2 6}$.

Concerning the structural misassignments presented above, we would like to reproduce some paragraphs of the fascinating work of Nicolaou and Snyder, ${ }^{87}$ entitled Chasing Molecules That Were Never There: Misassigned Natural Products and the Role of Chemical Synthesis in Modern Structure Elucidation:

"Although the past half century has witnessed a remarkable improvement in our ability to isolate and characterize complex natural products, mistakes are still a relatively common occurrence. 


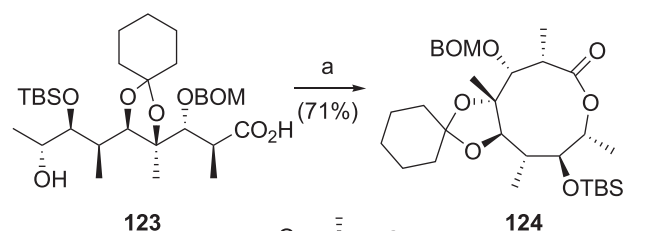

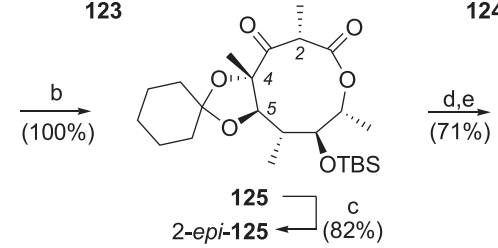

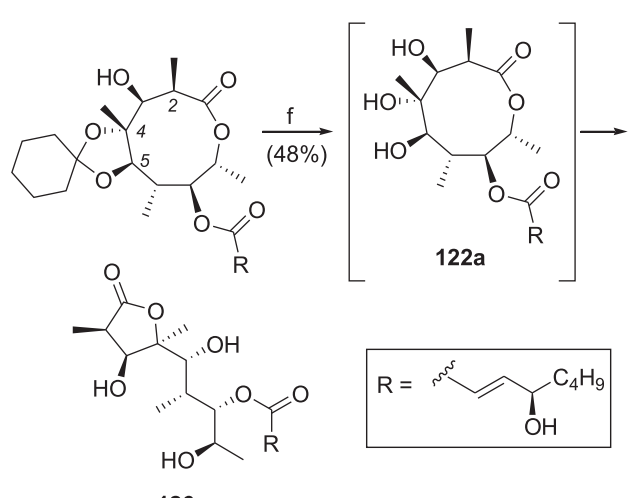

126

Scheme 21. Reagents and conditions: (a) MNBA, DMAP, $\mathrm{CH}_{2} \mathrm{Cl}_{2}, \mathrm{rt}, 4 \mathrm{~h}(7 \%$ of the dimer of 124); (b) $i: \mathrm{H}_{2}, \mathrm{Pd}(\mathrm{OH})_{2}, \mathrm{EtOH}, \mathrm{rt}, 15 \mathrm{~h}$; ii: TPAP, NMO, MS $4 \mathrm{~A}, \mathrm{CH}_{2} \mathrm{Cl}_{2}, \mathrm{O}^{\circ} \mathrm{C}, 3 \mathrm{~h}\left(125 / 2\right.$-epi-125 = 8/2); (c) preparative TLC; (d) $\mathrm{i}: \mathrm{NaBH}_{4}$, $\mathrm{MeOH}, \mathrm{O}^{\circ} \mathrm{C}, 2 \mathrm{~h}$; ii: DHP, CSA, $\mathrm{CH}_{2} \mathrm{Cl}_{2}, \mathrm{rt}, 1 \mathrm{~h}$; iii: TBAF, THF, $\mathrm{O}^{\circ} \mathrm{C}, 3 \mathrm{~h}$; (e) $i$ : TBS-protected 4-(R)-2-(E)-4-hydroxyoct-2-enoic acid, MNBA, Et ${ }_{3}$, DMAP, $\mathrm{CH}_{2} \mathrm{Cl}_{2}, \mathrm{rt}, 3.5 \mathrm{~h}$; ii: HF.Py, THF, rt, $3 \mathrm{~h}$; (f) $\mathrm{BBr}_{3}, \mathrm{CH}_{2} \mathrm{Cl}_{2},-45^{\circ} \mathrm{C}, 1.5 \mathrm{~h}$

However (...) this state of affairs is far from catastrophic. Indeed, structural misassignments clearly provide opportunities for synthetic chemists to make discoveries through total synthesis, and certainly show that there is still adventure to be had in the process of structure assignment. (...) we can be certain that as long as chemists continue to isolate new and diverse substances from nature, there will be plenty of challenges for our intellectual and physical skills. Moreover, much new science awaits discovery during the struggle to synthesize such new molecular puzzles".

\section{Eleven-membered ring lactones}

Few examples of eleven-membered lactones are found in Nature, similarly to what occurs with the eight- and nine-membered ones. Besides some structurally more complex pyrrolizidinic and daphniphyllum alkaloids, there are two insect pheromones - the ferrulactone I and the suspensolide - and three fungal metabolites the aspercyclides A-C - described in the literature.

\section{Ferrulactone I}

In 1983, Wong et al. $^{88}$ reported the isolation of two lactones from the frass of Cryptolestes ferrugineus (Stephens), the rusty grain beetle. These compounds, named ferrulactone I (127) and ferrulactone II (128), are aggregation pheromones produced by the male insects, and bear an eleven- and a twelve-membered ring lactone, respectively.

All the syntheses ${ }^{89-92}$ of ferrulactone I (127) described in literature start from geraniol. The first synthesis of $\mathbf{1 2 7}$ was reported in 1983 by Oehlschlager et al., ${ }^{89}$ which obtained the cyclic intermediate $\mathbf{1 3 2}$ by intramolecular alkylation of the $\omega$-bromo-geraniol derivative $\mathbf{1 3 1}$.

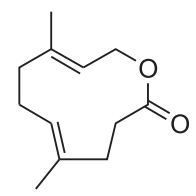

ferrulactone I (127)

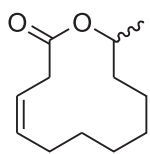

ferrulactone II (128)
This intermediate was prepared by reaction of geraniol 129 with (phenylthio)acetyl chloride, followed by allylic oxidation in C8 and bromination of the alcohol thus obtained. Finally, desulfurization of 132 afforded the target molecule in $10 \%$ global yield (Scheme 22).

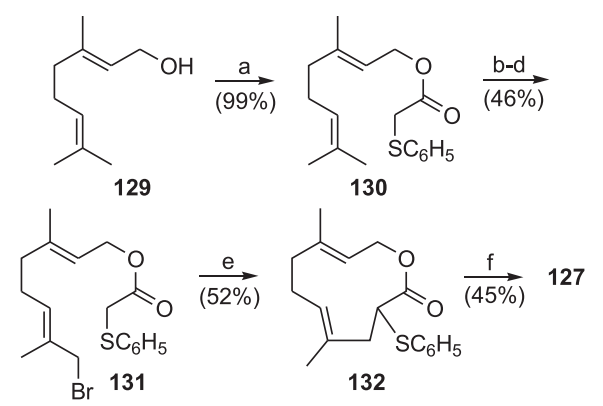

Scheme 22. Reagents and conditions: (a) $\mathrm{C}_{6} \mathrm{H}_{5} \mathrm{SCH}_{2} \mathrm{C}(\mathrm{O}) \mathrm{Cl}, \mathrm{Py}, \mathrm{CH}_{2} \mathrm{Cl}_{2}, \mathrm{O}$ ${ }^{\circ} \mathrm{C}, 3 \mathrm{~h}$; (b) $\mathrm{SeO}_{2}, \mathrm{Py}$, EtOH, reflux, $4.5 \mathrm{~h}$; (c) $\mathrm{NaBH}_{3} \mathrm{C} \equiv \mathrm{N}, \mathrm{THF}, \mathrm{O}^{\circ} \mathrm{C}, 1 \mathrm{~h}$, then $23{ }^{\circ} \mathrm{C}$ for $18 \mathrm{~h}$; (d) $\mathrm{CBr}_{4}, \mathrm{PPh}_{3}, \mathrm{Et}_{2} \mathrm{O}, 23{ }^{\circ} \mathrm{C}, 20 \mathrm{~h}$; (e) NaH, HMPA, THF, reflux, $23 \mathrm{~h}$; (f) Ni-Ra, EtOH, rt, $1 \mathrm{~h}$

In the same paper, ${ }^{89}$ an alternative approach to ferrulactone $\mathbf{1 2 7}$ was also described. The key step consists of an intramolecular esterification ${ }^{93}$ of the dienoic acid 134, prepared by formal addition of acetate anion equivalent to tetrahydropyranyl-protected $8(E)$-bromogeraniol 133. The best yield obtained for the eleven-membered lactone 127 was $37 \%$, when bis(4-tert-butyl- $N$-isopropylimidazol-2-yl)disulfide (BID) ${ }^{93}$ was used as activating reagent and the temperature of the reaction medium was carefully controlled (Scheme 23).

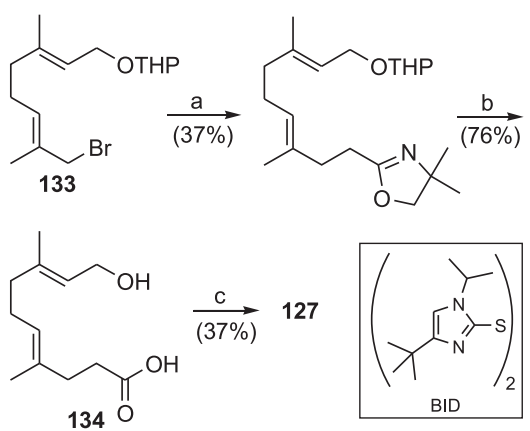

Scheme 23. Reagents and conditions: (a) 2,4,4-trimethyl-2-oxozoline, $n$-BuLi, THF, $-78^{\circ} \mathrm{C}, 1 \mathrm{~h}$; (b) i: MeI (excess), rt; overnight; ii: $1 \mathrm{Naq} . \mathrm{NaOH}, \mathrm{rt}, 20 \mathrm{~h}$; iii: Dowex 50W-X8, MeOH, rt, $1 \mathrm{~h}$; (c) $i: \mathrm{BID}, \mathrm{PPh}_{3}$, toluene, $-68^{\circ} \mathrm{C} \rightarrow-10^{\circ} \mathrm{C}$, $2.5 \mathrm{~h}$; ii: addition of cold toluene, $-35 \rightarrow 23^{\circ} \mathrm{C}$, then reflux, $2 \mathrm{~h}$

The cyclization of $\mathbf{1 3 5}$ under the action of zerovalent palladium, followed by sodium amalgam-promoted desulfurization of the elevenmembered lactone intermediate, also afforded the ferrulactone I (127), as described by Kukovinets et al. ${ }^{90}$ (Scheme 24).

Another synthesis of $\mathbf{1 2 7}$ in which the key step is a lactonization of a seco acid was reported by Cheskis et al. ${ }^{91}$ The Claisen rearrangement of allylic alcohol $\mathbf{1 3 6}$ proceeded stereospecifically to furnish the ester $\mathbf{1 3 7}$ in $95 \%$ yield as a single $(E, E)$-isomer 
<smiles>C/C(=C/CC/C(C)=C/COC(=O)[18OH])COC(=O)OCC(C)(C)C</smiles>

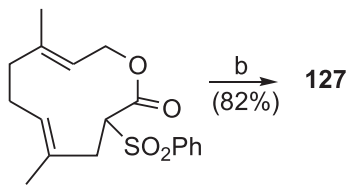

Scheme 24. Reagents and conditions: (a) $i: \mathrm{NaH}, \mathrm{THF}, 0^{\circ} \mathrm{C}, 15 \mathrm{~min}$, then $\mathrm{rt}$, 30 min. ii: $\mathrm{Pd}\left(\mathrm{PPh}_{3}\right)_{4}$, bisdephenylphosphineethylene, $\mathrm{O}^{\circ} \mathrm{C}$; (b) sodium amalgam, $\mathrm{EtOH}, \mathrm{AcOH},-20^{\circ} \mathrm{C} \rightarrow \mathrm{rt}, 2.5 \mathrm{~h}$

(Scheme 25). Removal of THP protecting group followed by ester hydrolysis led the $\omega$-hydroxyacid $\mathbf{1 3 4}$, which was submitted to latonization using BID, similarly to what was previously reported by Oehlschlager et al. $^{90}$

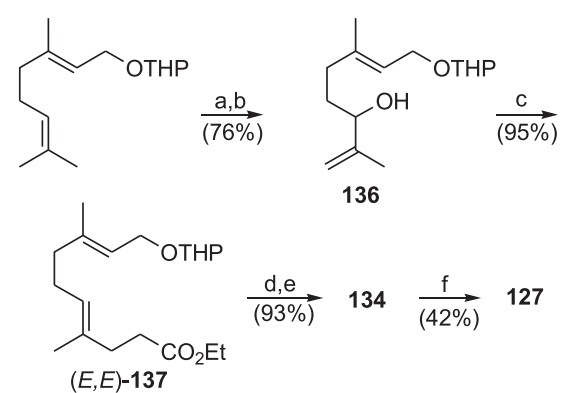

Scheme 25. Reagents and conditions: (a) $\mathrm{MCPBA}, \mathrm{AcONa}, \mathrm{CH}_{2} \mathrm{Cl}_{2}, \mathrm{O}^{\circ} \mathrm{C}, 30$ min, then $20^{\circ} \mathrm{C}, 1.5 \mathrm{~h}$; (b) (i-PrO) ${ }_{3} \mathrm{Al}$, toluene, reflux, $6 \mathrm{~h}$; (c) TMOF, $\mathrm{CH}_{3} \mathrm{CH}_{2} \mathrm{CO}_{2} \mathrm{H}, 135^{\circ} \mathrm{C}, 1.5 \mathrm{~h}$; (d) PTSA, Py, EtOH, $55^{\circ} \mathrm{C}, 4 \mathrm{~h}$; (e) aq. $\mathrm{KOH}$, $\mathrm{MeOH}, \mathrm{rt}, 1 \mathrm{~h}$; (f) BID, toluene, $\mathrm{PPh}_{3},-75^{\circ} \mathrm{C}, 30 \mathrm{~min}$, then $-10^{\circ} \mathrm{C}, 1.5 \mathrm{~h}$

Moriya et al. ${ }^{92}$ obtained the ferrulactone (127) in a short fourstep synthesis, also starting from geraniol (Scheme 26). An intramolecular Reformatsky reaction of $\omega$-bromoacetoxy aldehyde 138 led to the eleven-membered lactone intermediate 139, which was submitted to selective allylic debenzoylation promoted by $\mathrm{SmI}_{2}$ in THF-HMPA.

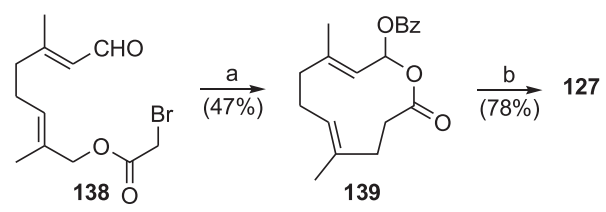

Scheme 26. Reagents and conditions: (a) $\mathrm{SmI}_{2}-\mathrm{THF}, \mathrm{BzC}(\mathrm{O}) \mathrm{Cl}$, DMAP, rt; (b) $\mathrm{SmI}_{2}$-THF-HMPA, 2,2-dimethyl propanoic acid, $0{ }^{\circ} \mathrm{C}$

\section{Suspensolide}

Suspensolide (140), which is a regioisomer of ferrulactone I (127), was isolated in 1988 from the male Caribbean fruit fly Anastrepha suspensa (Loew), together with anastrephin (141) and epianastrephin (142). ${ }^{94}$ Later, 140 was reported to be also produced by A. ludens, ${ }^{95}$ and A. fraterculus. ${ }^{96}$

Studies concerning some biosynthetic aspects of suspensolide (140) were published by Battiste et al. ${ }^{97}$ Thus, acid-catalyzed rearrangement of 140 to anastrephin (141) and epianastrephin (142) was carried out by treatment with $\mathrm{BF}_{3}$. Et $\mathrm{O}_{2} \mathrm{O}$, as depicted in Scheme 27 .

The same authors ${ }^{98}$ developed a conformational analysis of suspensolide (140), by molecular modeling and NMR studies, and concluded that the two most stable conformers have the methyl groups in a syn position.

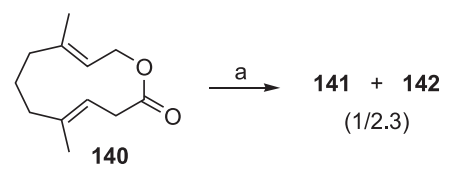

Scheme 27. Reagents and conditions: (a) $\mathrm{BF}_{3} . \mathrm{EtO}_{2}, \mathrm{Et}_{2} \mathrm{O}, 23^{\circ} \mathrm{C}, 0.5 \mathrm{~h}$

The complete assignments of the ${ }^{1} \mathrm{H}-\mathrm{NMR}$ and ${ }^{13} \mathrm{C}$-NMR spectra of the lactones suspensolide (140), anastrephin (141) and epianastrephin (142) have been accomplished by Baker and Heath. ${ }^{99}$

Battiste et al. ${ }^{100}$ reported a short synthesis of suspensolide (140) from mesityl oxide and proved the $(3 E, 8 E)$-geometry of the double bonds of this natural product. The key hydroxyacid 143 was submitted to lactonization under Mitsunobu conditions ${ }^{73}$ to afford 140 in only $25 \%$ isolated yield (Scheme 28 ).

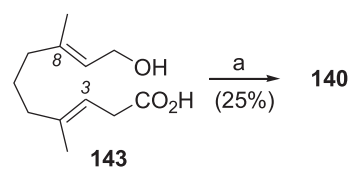

Scheme 28. Reagents and conditions: (a) DEAD, PPh, benzene, rt, $72 \mathrm{~h}$

In the same year, Mori and Nakazono ${ }^{101}$ reported the synthesis of 140 also using the Mitsunobu lactonization ${ }^{73}$ of 143 , which afforded the desired eleven-membered lactone in a very poor yield (ca. 9\%). The key hydroxyacid $\mathbf{1 4 3}$ was prepared from geraniol in a fifteen-step sequence of reactions.

A stereospecific synthesis of suspensolide (140) was achieved by Del Vecchio and Oelschlager. ${ }^{102}$ The synthesis started with 1,6heptadiyne which was converted into the diol 145 by a double carboalumination with in situ conversion to a dialanate intermediate followed by reaction with paraformaldehyde (Scheme 29). THPmonoprotection of $\mathbf{1 4 5}$, conversion of free hydroxyl group to chloride and cyanide substitution under phase-transfer conditions led to the nitrile 146, which could not be directly hydrolyzed to the corresponding carboxylic acid without isomerization of the double bond. Thus, 146 was alternatively converted into the amide $\mathbf{1 4 7}$ followed by a very mild hydrolysis, leading to the desired acid 148. Lactonization of $\mathbf{1 4 3}$ under Mitsunobu conditions, ${ }^{73}$ as already reported by Battiste et al., ${ }^{100}$ also led to suspensolide $\mathbf{1 4 0}$ in poor

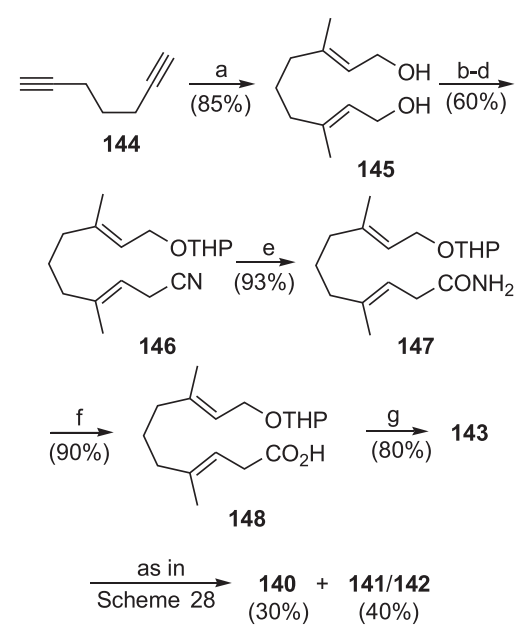

Scheme 29. Reagents and conditions: (a) $\mathrm{i}: \mathrm{AlMe} \mathrm{ZrCp}_{2} \mathrm{Cl}_{2}, \mathrm{ClCH}_{2} \mathrm{CH}_{2} \mathrm{Cl}$, $\mathrm{O}^{\circ} \mathrm{C}, 3 \mathrm{~h}$; ii: $n$-BuLi, THF, $\left(\mathrm{CHO}_{2}\right)_{n},-78^{\circ} \mathrm{C}$, overnight; (b) DHP, Et $t_{2} \mathrm{O}, \mathrm{PTSA}$, rt; (c) $\mathrm{NCS}, \mathrm{CH}_{2} \mathrm{Cl}_{2}, \mathrm{DMS}, \mathrm{O}^{\circ} \mathrm{C}, 1 \mathrm{~h}$; (d) $\mathrm{KCN}, \mathrm{CH}_{3} \mathrm{CN}, 18$-crown-6, rt, $12 \mathrm{~h}$; (e) $\mathrm{H}_{2} \mathrm{O}_{2}, \mathrm{n}-\mathrm{Bu}_{4} \mathrm{HSO}_{4}, \mathrm{CH}_{2} \mathrm{Cl}_{2}, 20 \%$ aq. $\mathrm{NaOH}, \mathrm{rt}, 8 \mathrm{~h}$; (f) $\mathrm{Na}_{2} \mathrm{O}_{2}, \mathrm{H}_{2} \mathrm{O}, 80^{\circ} \mathrm{C}$, $8 \mathrm{~h} ;(\mathrm{g}) \mathrm{AcOH} / \mathrm{THF}_{\mathrm{EEt}} \mathrm{O}(4 / 2 / 1), 45^{\circ} \mathrm{C}, 4 \mathrm{~h}$ 
yield (30\%), along with a mixture of anastrephin (141) and epianastrephin (142), in $40 \%$ isolated yield.

A stereoselective four-step synthesis of the 10-hydroxy-4,8dimethyl-3(E),8(E)-dienoic acid (143), precursor of suspensolide (140), was described in 1996. ${ }^{103}$ The authors used the regioselective oxidation of the methyl group of geranyl acetate 149 with selenium oxide to obtain the aldehyde $\mathbf{1 5 0}$ in $53 \%$ yield. Wittig reaction followed by saponification led to the trienoic acid 151, which could be converted into the desired seco acid 143 by a regio- and stereoselective reduction of the conjugated diene moiety with lithium in liquid ammonia and methanol (Scheme 30).

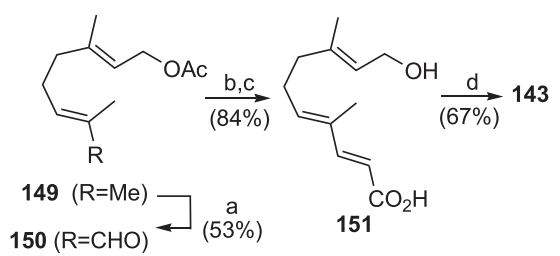

Scheme 30. Reagents and conditions: (a) $\mathrm{SeO}_{2}, \mathrm{EtOH}$, reflux, $1 \mathrm{~h}$; (b) $\mathrm{Ph}_{3} \mathrm{P}=\mathrm{CHCO}_{2} \mathrm{Et}, 100^{\circ} \mathrm{C}, 1 \mathrm{~h}$; (c) $\mathrm{KOH}, \mathrm{H}_{2} \mathrm{O}, \mathrm{MeOH}, 23^{\circ} \mathrm{C}, 72 \mathrm{~h}$; (d) Li, liq. $\mathrm{NH}_{3}, \mathrm{MeOH}$, reflux, $15 \mathrm{~min}$

It is of note that an eleven-membered lactone $(2,4,6,8$ tetramethyl-3,4-dihydroxydec-8(9)-enolide), structurally related to suspensolide, was recently isolated from the fungus Botrytis cynerea (Figure 2), along with some botcinolide derivatives. ${ }^{83}$

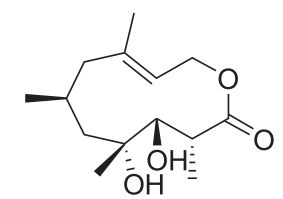

Figure 2. 2,4,6,8-Tetramethyl-3,4-dihydroxydec-8(9)-enolide

\section{Aspercyclides}

Aspercyclides A-C (152-154) are biphenylether-lactones isolated from an extract of Aspergillus sp. ${ }^{104}$ Aspercyclide A (152) showed to be inhibitor of the $\mathrm{IgE}$ receptor binding $\left(\mathrm{IC}_{50}=200 \mu \mathrm{M}\right)$, thus having a moderate anti-inflammatory effect. Compounds with this biological action may be efficacious in the treatment of allergic diseases such as asthma and rhinitis.

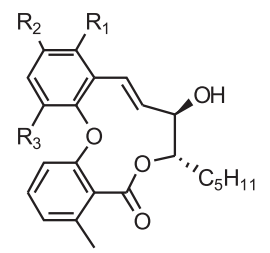

(+)-aspercyclide A (152) $\left(\mathrm{R}_{1}=\mathrm{CHO}, \mathrm{R}_{2}=\mathrm{OH}, \mathrm{R}_{3}=\mathrm{H}\right)$ (+)-aspercyclide $\mathrm{B}(153)\left(\mathrm{R}_{1}=\mathrm{CH}_{2} \mathrm{OH}, \mathrm{R}_{2}=\mathrm{OH}, \mathrm{R}_{3}=\mathrm{H}\right)$ $(+)$-aspercyclide $C(154)\left(R_{1}=R_{2}=H, R_{3}=O H\right)$

The first reported total synthesis of (+)-aspercyclide C (154) was achieved by Fürstner and Müller ${ }^{105}$ through a kinetically controlled RCM reaction to form the eleven-membered ring (Scheme 31). The straightforward preparation of diaryl acid $\mathbf{1 5 5}$ was possible by an Ullmann coupling of a bromide with a phenol, followed by saponification of the ester function. An anti-selective oxy-allylation reaction led to the aliphatic fragment 156a, upon treatment of PMP-protected allyl alcohol with hexanal, a strong base and the $(S, S)-\mathbf{1 5 8}$ complex. Esterification of acid 155 with alcohol 156a was performed using the Mukaiyama method ${ }^{106}$ to furnish the dienoic ester 157. RCM of $\mathbf{1 5 7}$ with second generation
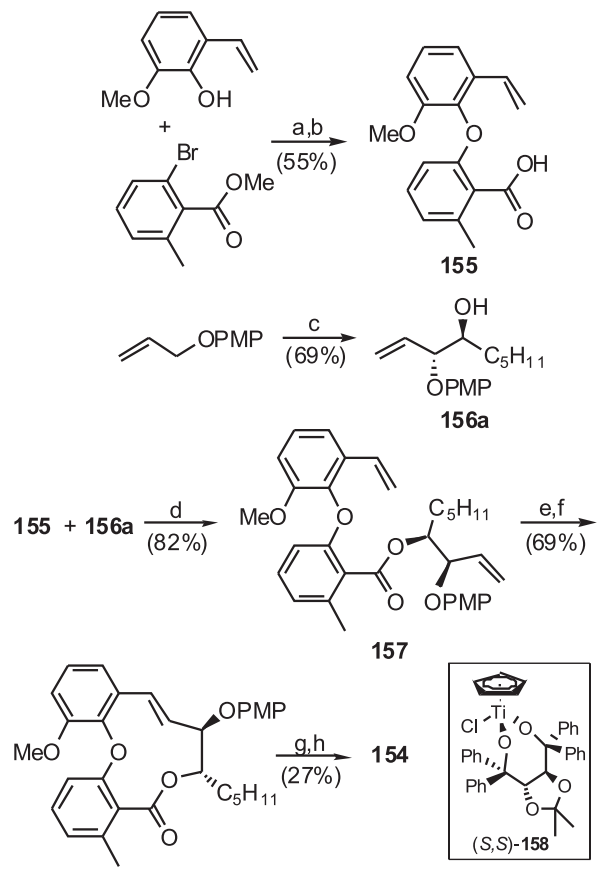

Scheme 31. Reagents and conditions: (a) $\mathrm{CuO}, \mathrm{K}_{2} \mathrm{CO}_{3}, \mathrm{Py}, 130^{\circ} \mathrm{C}$; (b) aq. $\mathrm{NaOH}, \mathrm{MeOH}$; (c) i: sec-BuLi; ii: hexanal, complex (S,S)-158, THF/Et $t_{2} \mathrm{O}$, $-78^{\circ} \mathrm{C}$; (d) $\mathrm{N}$-methyl-2-chloropyridinium iodide, $\mathrm{Et}_{3} \mathrm{~N}, \mathrm{CH}_{3} \mathrm{CN}$, reflux; (e) $2^{\text {nd }}$ generation Grubbs catalyst, toluene, reflux, $(f)$ chromatographic separation; (g) $\mathrm{CAN}, \mathrm{CH}_{3} \mathrm{CN} / \mathrm{H}_{2} \mathrm{O}, \mathrm{O}^{\circ} \mathrm{C}$; (h) $\mathrm{BBr}_{3}, \mathrm{CH}_{2} \mathrm{Cl}_{2},-78 \rightarrow 0^{\circ} \mathrm{C}$

Grubbs catalyst afforded the eleven-membered unsaturated lactones as a 5:1 mixture of $E$ and $Z$ isomers, respectively. Chromatographic separation followed by deprotection of hydroxyl groups of the $E$ isomer led to the $(+)$-aspercyclide $C(\mathbf{1 5 4})$.

Recently, a formal synthesis of (+)-aspercyclide C (154) was reported. ${ }^{107}$ The preparation of the PMB-protected linear fragment 156a was done using $D$-ribose acetonide as chiral pool (Scheme 32). Monoprotection of diol $\mathbf{1 5 9}$ led to a mixture of products, from which the desired product $\mathbf{1 5 6}$ a could be isolated in only $41 \%$ yield.
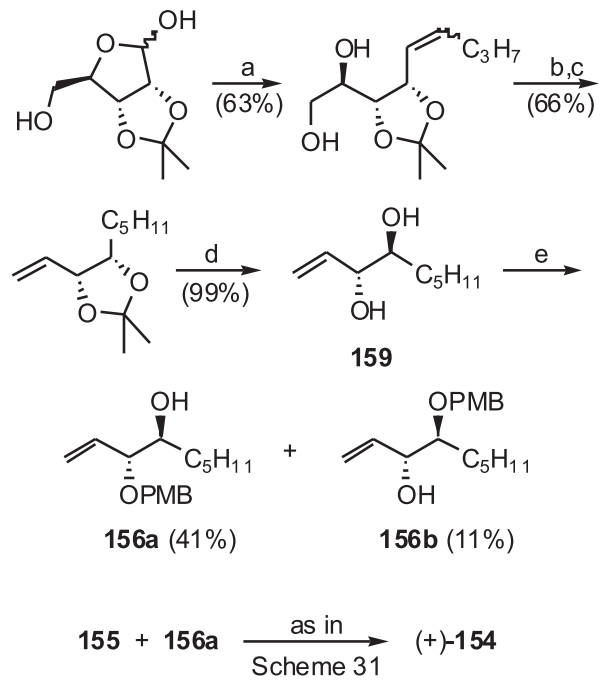

Scheme 32. Reagents and conditions: (a) $\mathrm{Ph}_{3} \mathrm{PCH}_{2} \mathrm{CH}_{2} \mathrm{CH}_{2} \mathrm{CH}_{3} \mathrm{Br}, \mathrm{t}-\mathrm{BuOK}$, $\mathrm{THF}, \mathrm{O}^{\circ} \mathrm{C} \rightarrow \mathrm{rt}, 16 \mathrm{~h}$; (b) $\mathrm{Ra}-\mathrm{Ni}, \mathrm{H}_{2}, \mathrm{EtOH}, \mathrm{rt}$; (c) $\mathrm{i}: \mathrm{MsCl}, \mathrm{Et}_{3} \mathrm{~N}, \mathrm{CH}_{2} \mathrm{Cl}_{2}, \mathrm{O}^{\circ} \mathrm{C}$, 3 h; ii: Zn, NaI, DMF, $155^{\circ} \mathrm{C}, 2 \mathrm{~h}$; (d) PTSA, MeOH, rt, $24 \mathrm{~h}$; (e) PMBCl, $\mathrm{NaH}, \mathrm{DMF}, \mathrm{O}^{\circ} \mathrm{C} \rightarrow \mathrm{rt}, 10 \mathrm{~h}$ (20\% recovery of 159); (f) ) N-methyl-2chloropyridinium iodide, $\left.\mathrm{Et}_{3} \mathrm{~N}, \mathrm{CH}_{3} \mathrm{CN}, 120^{\circ} \mathrm{C}, 1 \mathrm{~h} ; \mathrm{g}\right) 2^{\text {nd }}$ generation Grubbs catalyst, toluene, reflux, $3 \mathrm{~h}$; (h) $\mathrm{BBr}_{3}, \mathrm{CH}_{2} \mathrm{Cl}_{2},-78^{\circ} \mathrm{C}, 5 \mathrm{~min}$ 
Mukaiyama coupling ${ }^{106}$ of alcohol 156a with acid 155 (see Scheme 31 ), second generation Grubbs catalyst-mediated RCM of the dienoic ester intermediate and PMB-deprotection led to (+)aspercyclide $\mathrm{C}(\mathbf{1 5 4})$, following a similar sequence of reactions early described by Fürstner and Müller. ${ }^{105}$

\section{Alkaloids}

In 2006, the alkaloid (+)-macropodumine A (160) was isolated from the stem of Daphniphyllum macropodum, a plant used in Chinese traditional medicine in the treatment of inflammations. ${ }^{108}$ This metabolite has a fused pentacyclic system including an elevenmembered lactone, a structure feature never found before within the Daphniphyllum alkaloid family.

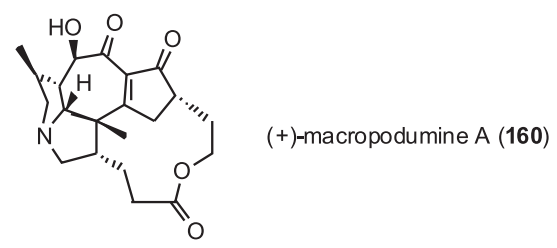

Eight others Daphniphyllum alkaloids, namely macropodumines B-I, have also been found in D. macropodum, ${ }^{109}$ but these molecules are not medium ring lactones. To our knowledge, there are no synthetic approaches for macropodumine A (160) described in the literature.

Some eleven-membered dilactone having a pyrrolizidine moiety were isolated from several species of Crotalaria. ${ }^{110}$ The hepatotoxic and carcinogenic monocrotaline (161) (Figure 3) is the most abundant alkaloid in this family of secondary metabolites, being isolated from C. lechnaultii, ${ }^{111}$ C. grahamiana, ${ }^{112}$ C. crispata, ${ }^{113}$ C. fulva ${ }^{114}$ and several others species of this genus. ${ }^{115}$ Others representative examples of the pyrrolizidine alkaloids with these structure features are dicrolataline (162), ${ }^{116}$ fulvine (163), ${ }^{113,114}$ and crispatine (164). ${ }^{111,114}$

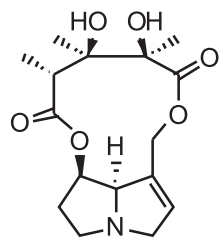

monocrotaline (161)

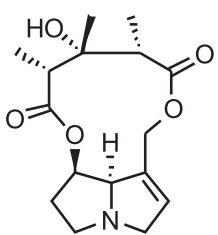

fulvine (163)

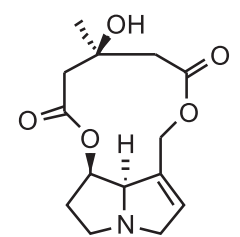

dicrotaline (162)

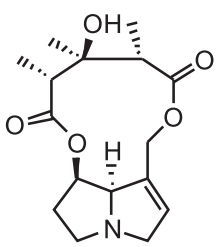

crispatine (164)
Figure 3. Some eleven-membered dilactones bearing a pyrrolizidine moiety

The natural occurrence and biological properties of these elevenmembered dilactones, among others pyrrolizidine compounds, were reviewed in the series articles published in the journal Natural Products Reports. ${ }^{117}$ The synthesis of 161-164 ${ }^{118}$ and related dilactone pyrrolizidine alkaloids will not be discussed here.

\section{CONCLUSION}

This review has attempted to summarize the natural occurrence, the biological properties as well as the enormous efforts toward the synthesis of the natural eight-, nine-, and eleven-membered lactones known to date.

In contrast to what was stated by Kao in $1997,{ }^{1}$ this challenging class of natural products has been stimulating chemists to develop new methodologies to construct the medium ring lactone core. Thus, several successful syntheses of the title compounds can be found in the literature.

It must be highlighted the increasing use of RCM to achieve the medium ring lactones, as already observed for the synthetic approaches to the ten-membered ring lactones, recently reviewed by us. ${ }^{3}$ Nevertheless, the use of the lactonization methods developed by Corey-Nicolaou, ${ }^{14}$ Yamaguchi $^{34}$ and Mitsunobu ${ }^{73}$ is still remarkable.

Although much success has been obtained in the syntheses described here, many of the natural eight-, nine-, and elevenmembered lactones have never been synthesized. Thus, we hope to see new exciting synthetic studies reported soon.

\section{AKNOWLEDGMENTS}

The authors wish to thank FAPESP, CNPq, and CAPES for financial support. We are also grateful to Prof. L. F. Silva Jr. for his constant cooperation and encouragement, and to M. V. Craveiro for critically reading of the manuscript.

\section{REFERENCES}

1. Kao, C. M.; McPherson, M.; McDaniel, R. N.; Fu, H.; Cane, D. E.; Khosla, C.; J. Am. Chem. Soc. 1997, 119, 11339.

2. For general reviews concerning the preparation methods of medium ring lactones, see: Rousseau, G.; Tetrahedron 1995, 51, 2777; Longo Jr., L. S.; Bombonato, F. I.; Ferraz, H. M. C.; Quim. Nova 2007, 30, 415.

3. Ferraz, H. M. C.; Bombonato, F. I.; Longo, Jr, L. S.; Synthesis 2007, 3261.

4. Riatto, V. B.; Pilli, R. A.; Victor, M. M.; Tetrahedron 2008, 64, 2279.

5. Shiina, I.; Chem. Rev. 2007, 107, 239.

6. Sassa, T.; Niwa, G.; Unno, H.; Ikeda, M.; Miura, Y.; Tetrahedron Lett. 1974, 3941.

7. Suzuki, K.; Nozawa, K.; Udagawa, S.-i.; Nakajima, S.; Kawai, K.-i.; Phytochemistry 1991, 30, 2096.

8. Proksa, B.; Uhrín, D.; Adamcová, J.; Fuska, J.; J. Antibiot. 1992, 45, 1268

9. Komai, S.-i.; Hosoe, T.; Itabashi, T.; Nozawa, K.; Yaguchi, T.; Fukushima, K.; Kawai, K.-i.; J. Nat. Med. 2006, 60, 185.

10. Tomoda, H.; Nishida, H.; Masuma, R.; Cao, J.; Okuda, S.; Omura, S.; J. Antibiot. 1991, 44, 136; Nishida, H.; Tomoda, H.; Cao, J. Okuda, S.; Omura, S.; J. Antibiot. 1991, 44, 144; Nishida, H.; Tomoda, H.; Cao, J.; Araki, S. Okuda, S.; Omura, S.; J. Antibiot. 1991, 44, 152.

11. Salituro, G. M.; Pettibone, D. J.; Clineschmidt, B.V.; Williamson, J. M.; Zink, D. L.; Bioorg. Med. Chem. Lett. 1993, 3, 337.

12. Brückner, D.; Hafner, F.-T.; Li, V.; Schmeck, C.; Telser, J.; Vakalopoulos, A.; Wirtz, G.; Bioorg. Med. Chem. Lett. 2005, 15, 3611.

13. Delgado, A.; Clardy, J.; J. Org. Chem. 1993, 58, 2862, and references cited therein.

14. Corey, E.J.; Nicolaou, K. C.; J. Am. Chem. Soc. 1974, 96, 5614.

15. Ackland, M. J.; Hanson, J. R.; Hitchcock, P. B.; Ratcliffe, A. H.; J. Chem. Soc., Perkin Trans. 1 1985, 843.

16. Farooq, A.; Gordon, J.; Hanson, J. R.; Takahashi, J. A.; Phytochemistry 1995, 38, 557.

17. Wada, K.; Ishida, T.; J. Chem. Soc., Perkin Trans. 1 1979, 1154.

18. Li, X.; Yao, Y.; Zheng, Y.; Sattler, I.; Lin, W.; Arch. Pharmacal Res. 2007, 30,812 .

19. Oller-López, J. L.; Iranzo, M.; Mormeneo, S.; Oliver, E.; Cuerva, J. M.; Oltra, J. E.; Org. Biomol. Chem. 2005, 3, 1172.

20. Shiina, I.; Fukuda, Y.; Ishii, T.; Fujisawa, H.; Mukaiyama, T.; Chem. Lett. 1998, 831; Shiina, I.; Fujisawa, H; Ishii, T; Fukuda, Y.; Heterocycles 2000, 52, 1105.

21. Buszek, K. R.; Jeong, Y.; Sato, N; Still, P. C.; Muiño, P.L.; Ghosh, I.; Synth. Commun. 2001, 31, 1781.

22. Tapiolas, D. M.; Roman, M.; Fenical, W.; Stout, T. J.; Clardy, J.; J. Am. Chem. Soc. 1991, 113, 4682.

23. Buszek, K. R.; Sato, N.; Jeong, Y.; J. Am. Chem. Soc. 1994, 116, 5511; Buszek, K. R.; Jeong, Y.; Tetrahedron Lett. 1995, 36, 7189. 
24. McWilliams, J. C.; Clardy, J.; J. Am. Chem. Soc. 1994, 116, 8378.

25. O’Sullivan, P. T.; Buhr, W.; Fuhry, M. A. M.; Harrison, J. R.; Davies, J. E.; Feeder, N.; Marshall, D. R.; Burton, J. W.; Holmes, A. B.; J. Am. Chem. Soc. 2004, 126, 2194

26. Shiina, I.; Hashizume, M.; Yamai, Y.-s.; Oshiumi, H.; Shimazaki, T.; Takasuna, Y.-j.; Ibuka, R.; Chem. Eur. J. 2005, 11, 6601.

27. For some references on the synthesis of lactone moiety as well as of formal synthesis of octalactins A and B, see: Bach, J.; Berenger, R.; Garcia, J.; Vilarrasa, J.; Tetrahedron Lett. 1995, 36, 3425; Andrus, M. B.; Argade, A B.; Tetrahedron Lett. 1996, 37, 5049; Hulme, A. N.; Howells, G. E.; Tetrahedron Lett. 1997, 38, 8245; Bach, J.; Garcia, J.; Tetrahedron Lett. 1998, 39, 6761; Inoue, S.; Iwabuchi, Y.; Irie, H.; Hatakeyama, S.; Synlet 1998, 735; Buszek, K. R.; Sato, N.; Jeong, Y.; Tetrahedron Lett. 2002, 43 , 181; Shiina, I.; Kubota, M.; Oshiumi, H.; Hashizume, M.; J. Org. Chem 2004, 69, 1822; Shiina, I.; Oshiumi, H.; Hashizume, M.; Yamai, Y.-s.; Ibuka, R.; Tetrahedron Lett. 2004, 45, 543; Dinh, M.-T.; BouzBouz, S.; Peglion, J.-L.; Cossy, J.; Synlett 2005, 2851.

28. Aird, J. I.; Hulme, A. N.; White, J. W.; Org. Lett. 2007, 9, 631

29. Seo, Y.; Cho, K. W.; Rho, J. R.; Shin, J.; Kwon, B.-M.; Bok, S.-H.; Song, J. I.; Tetrahedron 1996, 52, 10583.

30. Nagle, D. G.; Gerwick, W. H.; Tetrahedron Lett. 1990, 31, 2995; Nagle, D. G.; Gerwick, W. H.; J. Org. Chem. 1994, 59, 7227.

31. Davoren, J. E.; Martin, S. F.; J. Am. Chem. Soc. 2007, 129, 510; Davoren, J. E.; Harcken, C.; Martin, S. F.; J. Org. Chem. 2008, 73, 391

32. White, J. D.; Martin, W. H. C.; Lincoln, C.; Yang, J.; Org. Lett. 2007, 9, 3481 .

33 Varadarajan, S.; Mohapatra, D. K.; Datta, A.; Tetrahedron Lett. 1998, 39, 1075; Mohapatra, D. K.; Yellol, G. S.; ARKIVOC 2003 (ix), 21.

34. Inanaga, J.; Hirata, K.; Saeki, H.; Katsuki, T.; Yamaguchi, M.; Bull. Chem. Soc. Jpn. 1979, 52, 1989

35. Ganzer, U.; Jakupovic, J.; Phytochemistry 1990, 29, 535.

36. Sang, S.; Cheng, X.; Fu, H.-Y.; Shieh, D.-E.; Bai, N.; Lapsley, K.; Stark, R. E.; Rosen, R. T.; Ho, C.-T.; Tetrahedron Lett. 2002, 43, 2547.

37. Marco, J. A.; Sanz-Cervera, J. F.; Yuste, A.; Jakupovic, J.; J. Nat. Prod. 1999, 62, 110.

38. Shigemori, H.; Shimamoto, S.; Sekiguchi, M.; Ohsaki, A.; Kobayashi, J.i.; J. Nat. Prod. 2002, 65, 82.

39. Tsoukatou, M.; Siapi, H.; Vagias, C.; Roussis, V.; J. Nat. Prod. 2003, 66, 444.

40. Dat, N. T.; Bae, K.; Wamiru, A.; McMahon, J. B.; Le Grice, S. F. J.; Bona, M.; Beutler, J. A.; Kim, Y. H.; J. Nat. Prod. 2007, 70, 839.

41. Kinjo, J.-e.; Furusawa, J.-i.; Nohara, T.; Tetrahedron Lett. 1985, 26, 6101.

42. Shirataki, Y.; Tagaya, Y.; Yokoe, I.; Komatsu, M.; Chem. Pharm. Bull. 1987, 35,1637

43. Barrero, A. F.; Sanchez, J. F.; Barron, A.; Rodriguez, I.; J. Nat. Prod. 1989 52,1334

44. Nohara, T.; Kinjo, J.; Furusawa, J.; Sakai, Y.; Inoue, M.; Shirataki, Y.; Ishibashi, Y.; Yokoe, I.; Komatsu, M.; Phytochemistry 1993, 33, 1207.

45. Fang, X.-P.; Anderson, J. E.; Qiu, X.-X.; Kozlowski, J. F.; Chang, C.-J.; McLaughlin, J. L.; Tetrahedron 1993, 49, 1563.

46. Mukai, C.; Yamashita, H.; Hirai, S.; Hanaoka, M.; McLaughlin, J. L.; Chem Pharm. Bull. 1999, 47, 131.

47. Bermejo, A.; Tormo, J. R.; Cabedo, N.; Estornell, E.; Figadère, B.; Cortes, D.; J. Med. Chem. 1998, 41, 5158; Bermejo, A.; Léonce, S.; Cabedo, N.; Andreu, I.; Caignard, D. H.; Atassi, G.; Cortes, D.; J. Nat. Prod. 1999, 62, 1106.

48. Blásquez, M. A.; Bermejo, A.; Zafra-Polo, M. C., Cortes, D.; Phytochem Anal. 1999, 10, 161.

49. Mereyala, H. B.; Joe, M.; Curr. Med. Chem. - Anti-Cancer Agents 2001 $1,293$.

50. Peris, E.; Cavé, A.; Estornell, E.; Zafra-Polo, M. C.; Figadère, B.; Cortes, D.; Bermejo, A.; Tetrahedron 2002, 58, 1335.

51. Although a corrected structure of almuheptolide A (78) has been proposed in ref. 50, the authors do not make any mention of incorrect assignments for almuheptolide B (79).

52. Niwa, H.; Wakamatsu, K.; Yamada, K.; Tetrahedron Lett. 1989, 30, 4543.

53. Kigoshi, H.; Niwa, H.; Yamada, K.; Stout, T. J.; Clardy, J.; Tetrahedron Lett. 1991, 32, 2427.

54. Proteau, P. J.; Rossi, J. V.; Gerwick, W. H.; J. Nat. Prod. 1994, 57, 1717.

55. Critcher, D. J.; Connolly, S.; Mahon, M. F.; Wills, M.; Tetrahedron Lett 1995, 36, 3763; Critcher, D. J.; Connolly, S.; Wills, M.; J. Org. Chem. 1997 62,6638 .

56. Takemoto, Y.; Baba, Y.; Saha, G.; Nakao, S.; Iwata, C.; Tanaka, T.; Ibuka, T.; Tetrahedron Lett. 2000, 41, 3653; Baba, Y.; Saha, G.; Nakao, S.; Iwata, C.; Tanaka, T.; Ibuka, T.; Ohishi, H.; Takemoto, Y.; J. Org. Chem. 2001, 66,81

57. Takahashi, T; Watanabe, H. Kitahara, T; Hetrocycles 2002, 58, 99.
58. Mohapatra, D. K.; Datta, A.; J. Org. Chem. 1998, 63, 642.

59. Critcher, D. J. Connolly, S.; Mahon, M. F.; Wills, M.; J. Chem. Soc., Chem Commun. 1995, 139

60. Luo, X.; Li, F.; Hong, J.; Lee, C.-O.; Sim, C. J.; Im, K. S.; Jung, J. H.; J. Nat. Prod. 2006, 69, 567

61. Bohlmann, F.; Zdero, C.; Jakupovic, J.; Gerke, T.; Wallmeyer, M.; King, R. M.; Robinson, H.; Liebigs Ann. Chem. 1984, 162.

62. Iguchi, K.; Kajiyama, K.; Miyaoka, H.; Yamada, Y.; J. Org. Chem. 1996, 61, 5998.

63. Dunshee, B. R.; Leben, C.; Keitt, G. W.; Strong, F. M.; J. Am. Chem. Soc. 1949, 71, 2436; van Tamelen, E. E.; Dickie, J. P.; Loomans, M. E.; Dewey, R. S.; Strong, F. M.; J. Am. Chem. Soc. 1961, 83, 1639, and references cited therein.

64. Wikstrom, M. K. F.; Berden, J. A.; Biochim. Biophys. Acta 1972, 283, 403; Miyoshi, H.; Tokutake, N.; Imaeda, Y.; Akagi, T.; Iwamura, H.; Biochim. Biophys. Acta 1995, 1229, 149; Kim, H.; Esser, L.; Hossain, M. B.; Xia, D.; Yu, C. A.; Rizo, J.; van der Helm, D.; Deisenhofer, J.; J. Am. Chem. Soc. 1999, 121, 4902.

65. Sakagami, Y.; Takeuchi, S.; Yonehara, H.; Sakai, H.; Takashima, M.; J. Antibiot. 1956, 9, 1; Leben, C.; Keitt, G. W.; Phytopathology 1949, 39, 529; Chen, G.; Lin, B.; Lin, Y.; Xie, F.; Lu, W.; Fong, W.-F.; J. Antibiot. 2005, 58, 519; Nakayama, K.; Okamoto, F.; Harada, Y.; J. Antibiot. 1956, 9, 63; Barrow, C.; Oleynek, J.; Marinelli, V.; Sun, H. H.; Kaplita, P.; Sedlock, D. M.; Gillum, A. M.; Chadwick, C. C.; Cooper, R.; J. Antibiot. 1997, 50, 729; Thorn, M. B; Biochem. J. 1956, 63, 420; Reif, A. E.; Potter, V. R.; Cancer Res. 1953, 13, 49; King, M. A.; Cytometry, Part A 2005, 63A, 69; Tzung, S.-P.; Kim, K. M.; Basañez, G.; Giedt, C. D.; Simon, J.; Zimmerberg, J.; Zhang, K. Y. J.; Hockenbery, D. M.; Nat. Cell Biol. 2001, 3,183 .

66. Abidi, S. L.; J. Chromatogr. 1988, 447, 65; Abidi, S. L.; J. Chromatogr. 1989, 464, 453

67. Kinoshita, M.; Wada, M.; Umezawa, S.; J. Antibiot. 1969, 22, 580.

68. Kinoshita, M.; Wada, M.; Aburagi, S.; Umezawa, S.; J. Antibiot. 1971, 24 , 724; Kinoshita, M.; Aburaki, S.; Wada, M.; Umezawa, S.; Bull. Chem. Soc. Jpn. 1973, 46, 1279.

69. Tsunoda, T.; Nishii, T.; Yoshizuka, M.; Yamasaki, C.; Suzuki, T.; Itô, S.; Tetrahedron Lett. 2000, 41, 7667.

70. Nishii, T.; Suzuki, S.; Yoshida, K.; Arakaki, K.; Tsunoda, T.; Tetrahedron Lett. 2003, 44, 7829 .

71. Wu, Y,; Yang, Y.-Q.; J. Org. Chem. 2006, 71, 4296.

72. For some references on the formal synthesis of the Antimycins $\mathrm{A}_{3}$, see: Aburaki, S.; Kinoshita, M.; Bull. Chem. Soc. Jpn. 1979, 52, 198; Nakata, T.; Fukui, M.; Oishi, T.; Tetrahedron Lett. 1983, 24, 2657; Wasserman, H. H.; Gambale, R. J.; J. Am. Chem. Soc. 1985, 107, 1423; Inghardt, T.; Frejd, T.; Tetrahedron 1991, 47, 6483; Wasserman, H. H.; Gambale, R. J.; Tetrahedron 1992, 48, 7059; Kondo, H.; Oritani, T.; Kiyota, H.; Heterocycl. Commun. 2000, 6, 211; Chakraborty, T. K.; Chattopadhyay, A. K.; Ghosh, S.; Tetrahedron Lett. 2007, 48, 1139.

73. Kurihara, T.; Nakajima, Y.; Mitsunobu, O.; Tetrahedron Lett. 1976, 2455.

74. Shiina, I.; Kubota, M.; Ibuka, R.; Tetrahedron Lett. 2002, 43, 7535; Shiina, I.; Kubota, M.; Oshiumi, H.; Hashizume, M.; J. Org. Chem. 2004, 69, 1822.

75. Birnbaum, G. I.; Hall, S. R.; J. Am. Chem. Soc. 1976, 98, 1926 and references cited therein.

76. Bycroft, B. W.; King, T. J.; J. Chem. Soc., Perkin Trans 1 1976, 1996; Bycroft, B. W.; J. Chem. Soc., Perkin Trans 1 1977, 2464.

77. For some references on the synthetic approaches to the sulfur-containing lactone moiety of griseoviridin, see: Meyers, A. I.; Lawson, J.; Amos, R. A.; Walker, D. G.; Spohn, R. F.; Pure Appl. Chem. 1982, 54, 2537; Butera, J.; Rini, J.; Helquist, P.; J. Org. Chem. 1985, 50, 3676; Liu, L.; Tanke, R. S.; Miller, M. J.; J. Org. Chem. 1986, 51, 5332; Marcantoni, E.; Massaccesi, M.; Petrini, M.; J. Org. Chem. 2000, 65, 4553; Kuligowski, C.; BezzenineLafollée, S.; Chaume, G.; Mahuteau, J.; Barrière, J.-C.; Bacqué, E.; Pancrazi, A.; Ardisson, J.; J. Org. Chem. 2002, 67, 4565; Moreau, X.; Campagne, J.-M.; J. Org. Chem. 2003, 68, 5346; Chaume, G.; Kuligowski, C.; Bezzenine-Lafollée, S.; Ricard, L.; Pancrazi, A.; Ardisson, J.; Synthesis 2004, 3029.

78. Dvorak, C. A.; Schmitz, W. D.; Poon, D. J.; Pryde, D. C.; Lawson, J. P.; Amos, R. A.; Meyers, A. I.; Angew. Chem., Int. Ed. 2000, 39, 1664.

79. Cutler, H. G.; Jacyno, J. M.; Harwood, J. S.; Dulik, D.; Goodrich, P. D.; Roberts, R. G.; Biosci. Biotech. Biochem. 1993, 57, 1980.

80. Jacyno, J. M.; Harwood, J. S.; Culter, H. G.; Dulik, D. M.; Tetrahedron 1994, 50, 11585

81. Cutler, H. G.; Parker, S. R.; Ross, S. A.; Crumley, F. G.; Schreiner, P. R.; Biosci. Biotech. Biochem. 1996, 60, 656.

82. Collado, I. G.; Aleu, J., Hernández-Galán, R.; Hanson, J. R.; Phytochemistry 1996, 42, 1621; Collado, I. G.; Aleu, J. Hernández-Galán, R.; Durán-Patrón, R.; Curr. Org. Chem. 2000, 4, 1261. 
83. Reino, J. L.; Durán-Patrón, R. M.; Daoubi, M.; Collado, I. G.; HernándezGalán, R.; J. Org. Chem. 2006, 71, 562.

84. Tani, H.; Koshino, H.; Sakuno, E.; Cutler, H. G.; Nakajima, H.; J. Nat. Prod. 2006, 69, 722

85. Chakraborty, T. K.; Goswami, R. K.; Tetrahedron Lett. 2006, 47, 4917.

86. Shiina, I.; Takasuma, Y.-j.; Suzuki, R.-S.; Oshiumi, H.; Komiyama, Y.; Hitomi, S.; Fukui, H.; Org. Lett. 2006, 8, 5279.

87. Nicolaou, K. C.; Snyder, S. A.; Angew. Chem., Int. Ed. 2005, 44, 1012.

88. Wong, J. W.; Verigin,V.; Oehlschlager, A. C.; Borden, J. H.; Pierce, Jr., H. D.; Pierce, A. M.; Chong, L.; J. Chem. Ecol. 1983, 9, 451.

89. Oehlschlager, A. C.; Wong, J. W.; Verigin, V. G.; Pierce, Jr., H. D.; J. Org. Chem. 1983, 48, 5009.

90. Kukovinets, O. S.; Odinokov, V. N.; Tsyglintseva, E. Y.; Tolstikov, G. A.; Chem. Nat. Comp. 1996, 32, 909.

91. Cheskis, B. A.; Shpiro, N. A.; Moiseenkov, A. M.; Russ. Chem. Bull. 1989, 38, 2389.

92. Moriya, T.; Handa, Y.; Inanaga, J.; Yamaguchi, M.; Tetrahedron Lett. 1988, $29,6947$.

93. Corey, E.J.; Brunelle, D. J.; Tetrahedron Lett. 1976, 3409.

94. Chuman, T.; Sivinski, J.; Heath, R. R.; Calkins, C. O.; Tumlinson, J. H.; Battiste, M. A.; Wydra, R. L.; Strekowski, L.; Nation, J. L.; Tetrahedron Lett. 1988, 29, 6561; Ponce, W. P.; Nation, J. L.; Emmel, T. C.; Smittle, B. J.; Teal, P. E. A.; J. Chem. Ecol. 1993, 19, 3045.

95. Rocca, J. R.; Nation, J. L.; Strekowski, L.; Battiste, M. A. ;J. Chem. Ecol. 1992, 18, 223 .

96. Lima, I. S.; House, P. E.; Nascimento, R. R.; J. Braz. Chem. Soc. 2001, $12,196$.

97. Battiste, M. A.; Strekowski, L.; Coxon, J. M.; Wydra, R. L.; Harden, D. B.; Tetrahedron Lett. 1991, 32, 5303.

98. Wydra, R. L.; Harden, D. B.; Strekowski, L.; Battiste, M. A.; Coxon, J. M.; Tetrahedron 1992, 48, 3485.

99. Baker, J. D.; Heath R. R.; J. Chem. Ecol. 1993, 19, 1511.

100. Battiste, M. A.; Rocca, J. R.; Wydra, R. L.; Tumlinson, III, J. H.; Chuman, T.; Tetrahedron Lett. 1988, 29, 6565.
101. Mori, K.; Nakazono, Y.; Liebigs Ann. Chem. 1988, 167.

102. Del Vecchio, G. H.; Oehlschlager, A. C.; J. Org. Chem. 1994, 59, 4853

103. Battiste, M. A.; Wydra, R. L.; Strekowski, L.; J. Org. Chem. 1996, 61, 6454.

104. Singh, S. B.; Jayasuriya, H.; Zink, D. L.; Polishook, J. D.; Dombrowski, A. W.; Zweerink, H.; Tetrahedron Lett. 2004, 45, 7605.

105. Fürstner, A.; Müller, C.; Chem. Commun. 2005, 5583.

106. Mukaiyama, T.; Usui, M.; Shimada, E.; Saigo, K.; Chem. Lett. 1975, 1045.

107. Ramana, C. V.; Mondal, M. A.; Puranik, V. G.; Gurjar, M. K.; Tetrahedron Lett. 2007, 48, 7524.

108. Zhang, W.; Guo, Y.-W.; Krohn, K.; Chem. Eur. J. 2006, 12, 5122.

109. Li, Z.-Y.; Chen, P.; Xu, H.-G.; Yang, Y.-M.; Peng, S.-Y.; Zhao, Z.-Z.; Guo, Y.-W.; Org. Lett. 2007, 9, 477; Li, Z.-Y.; Chen, P.; Xu, H.-G.; Peng, S.-Y.; Yang, Y.-M.; Zhao, Z.-Z.; Guo, Y.-W.; Helv. Chim. Acta 2007, 90, 1353.

110. Jones, A. J.; Culvenor, C. C. J.; Smith, L. W.; Aust. J. Chem. 1982, 35 , 1173

111. Suri, O. P.; Atal, C. K.; Current Sci. 1967, 36, 614

112. Atal, C. K.; Culvenor, C. C. J.; Sawhney, R. S.; Smith, L. W.; Aust. J. Chem. 1969, 22, 1773 .

113. Culvenor, C. C. J.; Smith, L. W.; Aust. J. Chem. 1963, 16, 239.

114. Schoental, R.; Aust. J. Chem. 1963, 16, 233.

115. Pilbeam, D. J.; Lyon-Joyce, A. J.; Bell, E. A.; J. Nat. Prod. 1983, 46, 601.

116. Adams, R.; Van Duuren, B. L.; J. Am. Chem. Soc. 1953, 75, 2377.

117. Liddell, J. R. Nat. Pord. Rep. 2002, 19, 773; Liddell, J. R.; Nat. Pord. Rep. 2001, 18, 441, and earlier reviews in the series.

118. For some representative references on the synthesis of compounds 1-4, see: Vedejs, E.; Ahmad, S.; Larsen, S. D.; Westwood, S.; J. Org. Chem. 1987, 52, 3937; Niwa, H.; Okamoto, O.; Yamada, K.; Tetrahedron Lett. 1988, 29, 5139; Niwa, H.; Ogawa, T.; Okamoto, O.; Yamada, K.; Tetrahedron 1992, 48, 10531; Honda, T.; Tomitsuka, K.; Tsubuki, M.; J. Org. Chem. 1993, 58, 4274; Devlin, J. A.; Robins, D. J.; J. Chem. Soc., Chem. Commun. 1981, 1272; Brown, K.; Devlin, J. A.; Robins, D. J.; J. Chem. Soc., Perkin Trans. 1 1983, 1819; Niwa, H.; Okamoto, O.; Ishiwata, H.; Kuroda, A.; Uosaki, Y.; Yamada, K.; Bull. Chem. Soc. Jpn. 1988, 61, 3017; Vedejs, E.; Larsen, S. D.; J. Am. Chem. Soc.1984, 106, 3030. 